\title{
A Potential Visible-Light NO Releaser: Synthesis, Reactivity and Vasodilator Properties
}

\author{
Aurideia P. de Sousa, ${ }^{a}$ André F. Fernandes, ${ }^{a}$ Iury A. Paz, ${ }^{b}$ Nilberto R. F. Nascimento, ${ }^{b}$ \\ Javier Ellena, ${ }^{c}$ Eduardo H. S. Sousa, ${ }^{a}$ Luiz G. F. Lopes ${ }^{*, a}$ and Alda K. M. Holanda ${ }^{*, a}$ \\ ${ }^{a}$ Departamento de Química Orgânica e Inorgânica, Universidade Federal do Ceará, \\ Campus do Pici, Cx. Postal 12200, 60440-900 Fortaleza-CE, Brazil \\ ${ }^{b}$ Laboratório de Farmacologia Cardiovascular, Departamento de Medicina Veterinária, \\ Faculdade de Veterinária, Instituto Superior de Ciências Biomédicas, \\ Universidade Estadual do Ceará, Av. Paranjana, 1700, Itaperi, 60740-000 Fortaleza-CE, Brazil \\ 'Instituto de Física, Universidade de São Paulo, Cx. Postal 780, 13560-970 São Carlos-SP, Brazil
}

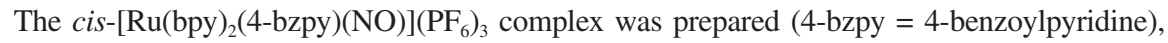
and characterized by UV-visible, infrared and nuclear magnetic resonance (NMR) spectroscopies and electrochemical techniques. The reaction with cysteine was preliminarily investigated, aiming to shed light on the potential biological mechanism for NO or HNO release mediated by thiols. Furthermore, photochemical behavior of $c i s-\left[\mathrm{Ru}(\mathrm{bpy})_{2}(4-\mathrm{bzpy})(\mathrm{NO})\right]\left(\mathrm{PF}_{6}\right)_{3}$ was studied, where it was observed NO release upon ultraviolet, blue and green light irradiations. This latter long wavelength showed still good efficiency, which has not been reported for this type of complex. This feature is very important for a potential application in phototherapy. Additionally, vasorelaxant activity was investigated in rat-isolated aorta. This compound exhibited a greater maximum efficacy than sodium nitroprusside (SNP) as a blood vessel relaxant. Nevertheless, the $\mathrm{EC}_{50}$ for $\mathrm{SNP}\left(13.3 \mathrm{nmol} \mathrm{L}^{-1}\right)$ was 52-fold smaller than the $\mathrm{EC}_{50}$ for cis-[Ru(bpy) $)_{2}(4$-bzpy $\left.) \mathrm{NO}\right]\left(\mathrm{PF}_{6}\right)_{3}\left(690 \mathrm{nmol} \mathrm{L}^{-1}\right)$. Altogether, these results suggest this complex is a promising NO donor agent deserving further biological studies.

Keywords: nitrosyl complexes, NO photorelease, vasorelaxing activity, metallodrugs

\section{Introduction}

Over 36 years have passed since seminal discovery of the biological relevance of nitric oxide (NO), which demonstrated that this molecule is involved in the regulation of a variety of physiological processes. ${ }^{1,2} \mathrm{NO}$ has been widely implicated in the platelet aggregation, memory function and vascular smooth muscle relaxation. ${ }^{3-6}$ Physiological unbalance of NO levels was shown to be involved in a variety of diseases, which has motivated a large number of investigations in chemistry, biology and medicine. Some successful clinical drugs that rely on downstream process of NO-sGC-cGMP (nitric oxide - soluble guanylate cyclase - cyclic guanosine monophosphate) pathway can face lack of efficiency due to non-activation of NO-mediated sGC. So, there is no doubt that molecules which modulate more upstream events can also show important pharmacological roles, e.g. nitroglycerin, nitroprusside. The development of compounds that release NO has evolved alongside with

*e-mail: lopeslu@dqoi.ufc.br; aldakarine@yahoo.com.br many discoveries in cardiovascular physiology and has moved toward therapeutic applications.

NO donors are pharmacologically active substances able to release nitric oxide spontaneously, after reduction by reducing biological agents or light irradiation. For example, in case of an emergency like a hypertension crisis or heart attacks, $\mathrm{NO}$ needs to be administered due to its vasodilator effect. Sodium nitroprusside ( $\mathrm{SNP}), \mathrm{Na}_{2}\left[\mathrm{Fe}(\mathrm{CN})_{5} \mathrm{NO}\right]$, is part of a class of compounds that release $\mathrm{NO}$ and is the unique NO metal complex used clinically. ${ }^{7}$ A comparison of the mechanisms underlying the relaxation induced by two nitric oxide donors, sodium nitroprusside and a ruthenium complex, ${ }^{7}$ showed that the ruthenium complex can indeed be used as a pharmacological tool without much toxicity, in contrast to SNP that is significantly more toxic. Thus, the development of new ruthenium-based drugs can represent an important advance in this field and many new systems have emerged with exciting biomedical applications, such as anti-parasitic, ${ }^{8}$ neuroprotection upon ischemia/reperfusion, ${ }^{9}$ gastroprotection, ${ }^{10}$ among others. ${ }^{11,12}$ In this context, we ${ }^{13-18}$ and others ${ }^{19-22}$ have developed a series of ruthenium nitrosyl 
compounds that could be further used as therapeutic agents. Most of the NO donor systems involve the release of NO by either a direct chemical bonding disruption or by a complex series of reaction, often requiring cellular metabolism. Therefore, it is also important to prepare compounds that can release NO upon a controlled external stimulation. One suitable stimulus is light, which can be used to promote NO photorelease from metalonitrosyl complexes as described elsewhere. ${ }^{14}$ In the course of probing photochemical NO releasers, da Silva and co-workers ${ }^{23}$ lab prepared some cis- $\left[\mathrm{Ru}(\mathrm{bpy})_{2} \mathrm{~L}(\mathrm{NO})\right]^{2+}$ complexes (L was pyridine, 4-picoline and 4-acetylpyridine), where their photochemical pathways were investigated. However, in that study, the release of nitric oxide was only achieved upon UV light irradiation $(355 \mathrm{~nm})$. Indeed, photorelease of NO using visible light is still a challenge. Having all this in mind, we prepared and investigated the reactivity of the $c i s-\left[\mathrm{Ru}(\mathrm{bpy})_{2}(\mathrm{~L})(\mathrm{NO})\right]\left(\mathrm{PF}_{6}\right)_{3}$ complex, where L was 4-benzoylpyridine (4-bzpy), and also conducted vasodilation measurements. The much extended $\pi$-system of the 4-benzoylpyridine ligand in comparison to previous ligands could cause a major impact on chemical and photochemical reactivity of nitrosyl ruthenium complex. This ligand might improve photoreactivity making possible to use visible light irradiation (453 and $505 \mathrm{~nm}$ ), which was explored here.

\section{Experimental}

\section{Materials}

Ultra high pure water from a Millipore system (Millipore Direct $\mathrm{Q}^{\circledR}$ 3UV) was used throughout the experiments. $\mathrm{RuCl}_{3} \cdot \mathrm{xH}_{2} \mathrm{O}$, 4-benzoylpyridine, 2,2'-bipyridine, sodium nitrite and cysteine were purchased from Sigma-Aldrich and used without any further purification. $c i s$ - $\left[\mathrm{Ru}(\mathrm{bpy})_{2} \mathrm{Cl}_{2}\right]$ was prepared according to procedure described in the literature. $^{24}$

\section{Synthesis of the complexes}

cis- $\left[\mathrm{Ru}(\mathrm{bpy})_{2}(\mathrm{~L})\left(\mathrm{NO}_{2}\right)\right]\left(\mathrm{PF}_{6}\right)$ (compound I)

The $c i s$ - $\left[\mathrm{Ru}(\mathrm{bpy})_{2}\left(4\right.\right.$-bzpy) $\left.\left(\mathrm{NO}_{2}\right)\right]\left(\mathrm{PF}_{6}\right)$ complex was prepared by following a procedure described elsewhere with minor modifications. ${ }^{15}$ This reaction was performed by mixing cis-[Ru(bpy $\left.)_{2} \mathrm{Cl}_{2}\right](0.200 \mathrm{~g}, 0.41 \mathrm{mmol})$ and 4-benzoylpyridine $(0.080 \mathrm{~g}, 0.43 \mathrm{mmol})$ in $20 \mathrm{~mL}$ of a 1:1 ethanol/water solution. This mixture was kept under reflux for $1 \mathrm{~h}$, and $\mathrm{NaNO}_{2}(0.034 \mathrm{~g}, 0.49 \mathrm{mmol})$ was added, allowing to react for more $2 \mathrm{~h}$, under reflux. This solution was concentrated by rotary evaporation to $10 \mathrm{~mL}$ and precipitated by the addition of saturated aqueous
$\mathrm{NH}_{4} \mathrm{PF}_{6}$ solution $(2 \mathrm{~mL})$. Yield $=80 \%$. IR $(\mathrm{KBr}$ disks $)$ $v_{\max } / \mathrm{cm}^{-1} 3117(\mathrm{C}-\mathrm{H}) ; 1667(\mathrm{C}=\mathrm{O}) ; 1446(\mathrm{C}-\mathrm{N}) ; 1338$ $\left(\mathrm{NO}_{2}^{-}\right.$, asymm); $1308\left(\mathrm{NO}_{2}^{-}\right.$, symm $) ;{ }^{1} \mathrm{H}$ nuclear magnetic resonance (NMR) $\left(500 \mathrm{MHz}\right.$, acetone- $\left.d_{6}\right) \delta 8.86(\mathrm{~d}$, bzpy-H, $\left.{ }^{22,25} J 5.50 \mathrm{~Hz}\right), 7.63$ (d, bzpy-H, ${ }^{23,26} J 6.00 \mathrm{~Hz}$ ), 7.81 (d, bzpy-H, $\left.{ }^{27,28} J 7.00 \mathrm{~Hz}\right), 7.57$ (t, bzpy-H, ${ }^{29,30}$ J 7.70 Hz), 7.72 (t, bzpy-H, ${ }^{31} J 6.90 \mathrm{~Hz}$ ). Anal. calcd. for $\mathrm{RuC}_{32} \mathrm{H}_{25} \mathrm{~N}_{6} \mathrm{O}_{3} \mathrm{PF}_{6}$, exp. (calcd.): C, 47.16 (48.8); H, 3.39 (3.20); N, $10.56 \%$ (10.67\%).

cis-[Ru(bpy) $\left.)_{2}(4-\mathrm{bzpy})(\mathrm{NO})\right]\left(\mathrm{PF}_{6}\right)_{3} \cdot \mathrm{H}_{2} \mathrm{O}$ (compound II)

The cis-[Ru(bpy $)_{2}$ (4-bzpy)(NO)]( $\left.\mathrm{PF}_{6}\right)_{3}$ complex was prepared by dissolving the $c i s-\left[\mathrm{Ru}(\mathrm{bpy})_{2} \mathrm{~L}\left(\mathrm{NO}_{2}\right)\right]\left(\mathrm{PF}_{6}\right)$ complex $(0.2 \mathrm{mmol})$ in methanol $(15 \mathrm{~mL})$ under an argon atmosphere. To this mixture, concentrated trifluoroacetic acid solution $(2 \mathrm{~mL}$ ) was added to promote the conversion of $\mathrm{NO}_{2}{ }^{-}$to $\mathrm{NO}^{+} .{ }^{26}$ After $2 \mathrm{~h}$, the mixture was concentrated in a rotary evaporator to ca. $8 \mathrm{~mL}$, and the solid was precipitated by the addition of $2 \mathrm{~mL}$ of $\mathrm{NH}_{4} \mathrm{PF}_{6} 0.89 \mathrm{~mol} \mathrm{~L}-1$. The solid was collected by filtration and stored under vacuum. Yield $=90 \%$. IR (KBr disks) $v_{\max } / \mathrm{cm}^{-1} 3120(\mathrm{C}-\mathrm{H}), 1942$ $\left(\mathrm{NO}^{+}\right), 1668(\mathrm{C}=\mathrm{O}), 1452(\mathrm{C}-\mathrm{N}) ;{ }^{1} \mathrm{H}$ NMR $(500 \mathrm{MHz}$, acetone- $\left.d_{6}\right) \delta 9.15\left(\mathrm{~d}\right.$, bzpy-H, $\left.{ }^{22,25} J 5.60 \mathrm{~Hz}\right), 7.98(\mathrm{~d}$, bzpy-H, $\left.{ }^{23,26} J 6.55 \mathrm{~Hz}\right), 7.77$ (d, bzpy-H, $\left.{ }^{27,28} J 7.35 \mathrm{~Hz}\right), 7.57$ (t, bzpy-H, $\left.{ }^{29,30} J 7.50 \mathrm{~Hz}\right), 7.72\left(\mathrm{t}\right.$, bzpy-H, $\left.{ }^{31} J 7.80 \mathrm{~Hz}\right)$. Anal. calcd. for $\mathrm{RuC}_{32} \mathrm{H}_{27} \mathrm{~N}_{6} \mathrm{O}_{3} \mathrm{P}_{3} \mathrm{~F}_{18}$, exp. (calcd.): C, 34.70 (35.60); H, 2.66 (2.52); N, 7.75\% (7.78\%).

\section{Apparatus}

Electrochemical experiments were performed in an electrochemical analyzer BAS Epsilon 2818 from Bioanalytical Systems. These measurements were generally performed using millimolar solutions of the complexes in $0.1 \mathrm{~mol} \mathrm{~L}^{-1} \mathrm{KCl}(\mathrm{pH}=2.0)$, employing conventional three electrode glass cell with a glassy carbon (ca. $0.13 \mathrm{~cm}^{2}$ of geometrical area), a Pt foil, and $\mathrm{Ag} / \mathrm{AgCl}$ (BAS, $3.5 \mathrm{M} \mathrm{KCl}$ ) as working, auxiliary and reference electrodes, respectively. The electrochemical experiments were done at room temperature.

Electronic spectra were acquired in a HP-8453 diodearray spectrophotometer in aqueous solution.

Fourier transform infrared (FTIR) spectra were obtained in an ABB Bomem FTLA 2000-102 spectrophotometer as $\mathrm{KBr}$ pellets.

NMR spectra for characterization of the complexes cis-[Ru(bpy) $)_{2}(4-$ bzpy $\left.)\left(\mathrm{NO}_{2}\right)\right]\left(\mathrm{PF}_{6}\right)$ and cis-[Ru(bpy $)_{2}\left(4\right.$-bzpy)(NO)] $\left(\mathrm{PF}_{6}\right)_{3}$ were obtained in a Bruker Avance DPX 500 spectrometer in $\mathrm{CD}_{3} \mathrm{COCD}_{3}$ and NMR spectra for monitoring the irradiation of the $c i s$ - $\left[\mathrm{Ru}(\mathrm{bpy})_{2}(4-\mathrm{bzpy})(\mathrm{NO})\right]\left(\mathrm{PF}_{6}\right)_{3}$ complex and 
characterization of the photoproducts were recorded on a Bruker DMX-500NMR spectrometer, in solution $\mathrm{CD}_{3} \mathrm{COCD}_{3} / \mathrm{D}_{2} \mathrm{O}(10: 90)$.

Single crystals were used for data collection and cell parameter determination on an Enraf-Nonius Kappa CCD diffractometer, using Mo K $\alpha$ radiation $(\mathrm{k}=0.71073 \AA)$. Data collection was made by using the COLLECT program; ${ }^{25}$ integration and scaling of the reflections were performed with the HKL Denzo-Scalepack system of programs. ${ }^{32}$ Absorption corrections were carried out using the multi-scan method..$^{33}$ The structure was solved by direct methods with SHELXS-97. ${ }^{27}$ The models were refined by full-matrix least-squares on F2 with SHELXL-97. ${ }^{29}$ All the hydrogen atoms were stereochemically positioned and refined with the riding model.

Modification of the Au electrode surface to be applied as a sensor for NO detection ${ }^{31}$

Initially, the gold electrode was mechanically polished with alumina, rinsed with Milli-Q water and sonicated in an ultrasonic bath for $10 \mathrm{~min}$, in order to remove possible contamination. The polycrystalline gold electrode was immersed in $\mathrm{H}_{2} \mathrm{SO}_{4}$ and $\mathrm{H}_{2} \mathrm{O}_{2}(3: 1 \mathrm{v} / \mathrm{v})$ for $3 \mathrm{~min}$ and rinsed thoroughly with water, followed by cyclic potential sweep at $0.1 \mathrm{~V} \mathrm{~s}^{-1}$ from 0.0 to $1.65 \mathrm{~V}$ (E vs. $\mathrm{Ag} / \mathrm{AgCl}$, saturated $\mathrm{KCl}$ ) range in a $1.0 \mathrm{~mol} \mathrm{~L}^{-1} \mathrm{H}_{2} \mathrm{SO}_{4}$. After this procedure, the polycrystalline Au electrode was immersed in $0.2 \mathrm{~mol} \mathrm{~L}^{-1}$ trans- $\left[\mathrm{Fe}(\text { cyclam })(\mathrm{NCS})_{2}\right]^{+}$ complex ion for $1 \mathrm{~h}$ immersion in order to carry out the film formation of the complex ion on the gold electrode surface $\left(\mathrm{Au} /\right.$ trans $\left.-\left[\mathrm{Fe}(\text { cyclam })(\mathrm{NCS})_{2}\right]^{+}\right)$. Square wave voltammograms for Au/trans- $\left[\mathrm{Fe}(\text { cyclam })(\mathrm{NCS})_{2}\right]^{+}$ electrode in $0.2 \mathrm{~mol} \mathrm{~L}^{-1} \mathrm{Na}_{2} \mathrm{SO}_{4}$ solution, $\mathrm{pH}=2.0$, containing cis-[Ru(bpy) ${ }_{2}(4 \text {-bzpy)NO }]^{3+}$ complex $\left(8.5 \times 10^{-4} \mathrm{~mol} \mathrm{~L}^{-1}\right)$, were obtained before and after the addition of cysteine $\left(8.5 \times 10^{-3} \mathrm{~mol} \mathrm{~L}^{-1}\right)$ and followed over time for a total time of 20 minutes, in order to detect the release of NO during the reaction of $c i s-\left[\mathrm{Ru}(\mathrm{bpy})_{2}(4-\mathrm{bzpy}) \mathrm{NO}\right]^{3+}$ complex with cysteine.

\section{Photochemical studies}

Photolysis experiments were carried out in $1.0-\mathrm{cm}$ pathlength quartz cells capped with a rubber septum at $25.0^{\circ} \mathrm{C}$. All solutions of the complexes were degassed by bubbling through argon prior to photolysis and stirred during irradiation. The solutions were photolyzed to approximately $5 \%$ of reaction to minimize inner filter effects. Control reactions were also performed in the dark to evaluate any thermal conversion during the time of these experiments.
Continuous photolysis was performed using a blue light emitting diode (LED) $\left(\lambda_{\max }=453 \mathrm{~nm}\right)$, a blue-green LED $\left(\lambda_{\max }=505 \mathrm{~nm}\right)$ or with the output from a $200 \mathrm{~W}$ high pressure mercury lamp mounted on an Oriel optical train passed through an interference filter to isolate the mercury line at $365 \mathrm{~nm}$. Lenses were used to collimate the light beam and a shutter was used to control the irradiation time. The light intensity was determined using chemical actinometry with potassium trisoxalatoferrate(III) at concentration of $0.006 \mathrm{~mol} \mathrm{~L}^{-1}$ as described in detail in the literature. ${ }^{28,30}$ Particularly at longer wavelength, LED with maximum at $505 \mathrm{~nm}$, quantum yield was measured using a more concentrated sample of trisoxalatoferrate(III) $\left(0.15 \mathrm{~mol} \mathrm{~L}^{-1}\right)$ to improve quantitative calculation as described elsewhere. ${ }^{34}$

Photoproducts were identified using NMR, UV-Vis spectroscopies and cyclic voltammetry, whose data were consistent with ruthenium complexes previously prepared. The formation of the cis-[Ru(bpy $)_{2}\left(4 \text {-bzpy) }\left(\mathrm{H}_{2} \mathrm{O}\right)\right]^{2+}$ species and NO release are equimolar. Based on that, we assumed that NO quantum yield measurement $\left(\Phi_{\mathrm{NO}}\right)$ and formation of the aqua species $\left(\Phi \mathrm{Ru}^{\mathrm{II}}\right)$ were identical. Accordingly, quantum yields were determined from initial spectral changes, monitoring the appearance of the cis-[Ru(bpy $)_{2}(4-$ bzpy $\left.)\left(\mathrm{H}_{2} \mathrm{O}\right)\right]^{2+}$ species at distinct irradiation times. Based on the known extinction coefficient for this product, it was plotted quantum yield versus percentage of the reaction. These data were extrapolated back to $0 \%$ reaction to minimize inner filter effects. A linear regression analysis was applied to these data, which provided an equation with y-intercept equal to the overall quantum yield. The quantum yields reported are the average of, at least, three independent experiments.

Quantum yields were determined by plotting the incremental quantum yields for the increase of a band at $450 \mathrm{~nm}$ (assigned to cis-[Ru(bpy) $)_{2}(4-$ bzpy $\left.)\left(\mathrm{H}_{2} \mathrm{O}\right)\right]^{2+}$ ) versus the elapsed irradiation time over the initial $10 \%$ of the reaction using light with maxima at $\lambda_{\text {irradiation }}=365,453$ and $505 \mathrm{~nm}$, as shown in Supplementary Information (SI) Figures S8, S9 and S10, respectively. Complex I aqueous solution exhibited absorbance at 365, 453 and $505 \mathrm{~nm}$ of $0.056,0.008$ and 0.003 , respectively.

\section{Kinetic experiments}

A solution containing the complex cis-[Ru(bpy $)_{2}$ (4-bzpy) (NO) $]\left(\mathrm{PF}_{6}\right)_{3}\left(8.5 \times 10^{-4}\right.$ to $\left.1.5 \times 10^{-4} \mathrm{~mol} \mathrm{~L}^{-1}\right)$ and cysteine was prepared upon fast mixing using stopped-flow (SF) technique, where cysteine concentrations varied from $8.5 \times 10^{-3}$ to $1.5 \times 10^{-3} \mathrm{~mol} \mathrm{~L}^{-1}$ ), in a citrate/ phosphate buffer solution, $\mathrm{pH}=2.2\left(0.40 \mathrm{~mL}\right.$ of $\mathrm{Na}_{2} \mathrm{HPO}_{4}$ $0.02 \mathrm{~mol} \mathrm{~L}^{-1} / 19.6 \mathrm{~mL}$ of citric acid $\left.0.1 \mathrm{~mol} \mathrm{~L}^{-1}\right)$. At least a 
10 -fold excess of cysteine over the complex was always kept to guarantee pseudo first-order conditions. This kinetics was followed using a stopped-flow device SX20 Applied Photophysics, and the spectral changes were recorded on the diode array spectrophotometer.

\section{Vasodilation assay}

Aortic rings preparation was done using male Wistar rats (180-200 g) killed under thiopental anesthesia, and the thoracic aorta was isolated, cleaned of adherent connective tissues, and cut into $4 \mathrm{~mm}$ of length rings. The aortic rings were mounted in $5 \mathrm{~mL}$ organ baths containing Krebs solution with the following composition (in $\mathrm{mmol} \mathrm{L}^{-1}$ ): $\mathrm{NaCl} 130$, $\mathrm{KCl} 4.7, \mathrm{KH}_{2} \mathrm{PO}_{4} 1.2, \mathrm{MgSO}_{4} 1.2, \mathrm{NaHCO}_{3} 14.9$, glucose $5.5, \mathrm{CaCl}_{2}$ 1.6. After a 60 -minute equilibration period, the tissues were contracted with phenylephrine $(0.1 \mu \mathrm{M})$, and concentration-response curves to SNP (as a positive control) or $c i s-\left[\mathrm{Ru}(\mathrm{bpy})_{2}(4\right.$-bzpy $\left.)(\mathrm{NO})\right]\left(\mathrm{PF}_{6}\right)_{3}$ were obtained in at least five independent experiments. The relaxant response was expressed as percentage decrease of the maximal contraction induced by phenylephrine. Concentrationresponse data were evaluated for a fit to a logistic function in the form: $y=$ bottom $+\frac{\text { (top }- \text { bottom })}{\left(1+10^{\left(\log E C_{50}-x\right) \times \text { hillslope) }}\right)}$. The concentration necessary to produce half of the maximal response of each drug $\left(\mathrm{EC}_{50}\right)$ was determined by a fourparameter nonlinear regression analyses by using GraphPad Prism (GraphPad Software, San Diego, CA, USA). All the protocols using animals were approved by the Animal Care and Use Committee of the Ceará State University under the number 2897836/15.

\section{Results and Discussion}

\section{A nitrite metal complex precursor}

Initially, the precursor, nitro complex, cis-[Ru(bpy $)_{2}\left(4\right.$-bzpy) $\left.\left(\mathrm{NO}_{2}\right)\right]\left(\mathrm{PF}_{6}\right)$ (I) (Scheme 1), was prepared, isolated and characterized by single-crystal X-ray diffraction analysis, elemental analysis, NMR and infrared spectroscopy. The infrared spectrum of this compound (SI, Figure S1) showed characteristic vibrational bands corresponding to the $v(\mathrm{C}=\mathrm{N})$ and $v(\mathrm{C}=\mathrm{C})$ modes of 4-bzpy ligand with overlapping bands of the bipyridine ligand in the wavenumber range of 1610 to $1400 \mathrm{~cm}^{-1}$. A band at $1665 \mathrm{~cm}^{-1}$ was attributed to $v(\mathrm{C}=\mathrm{O})$ of the ketone group as observed in 4-bzpy ligand structure, but absent in the cis- $\left[\mathrm{Ru}(\mathrm{bpy}){ }_{2} \mathrm{Cl}_{2}\right]$ compound. The $\mathrm{v}(\mathrm{C}=\mathrm{O})$ band, observed at $1667 \mathrm{~cm}^{-1}$, related to ketone group of 4-bzpy, suggested that this ligand is bounded to the ruthenium center. ${ }^{35}$ However, the most relevant feature in this infrared spectrum is associated to the vibration modes of the nitro group. Metal complexes bounded through the nitrogen show the symmetric $\left(v_{\text {sym }}\right)$ and asymmetric $\left(v_{\text {asym }}\right)$ stretching mode of $\mathrm{NO}_{2}^{-}$within $1300-1400 \mathrm{~cm}^{-1}$, where the asymmetric stretching exhibits a higher frequency value. ${ }^{36}$ This nitro complex showed strong absorptions at 1308 and $1338 \mathrm{~cm}^{-1}$, which can be attributed to the symmetric and asymmetric $v\left(\mathrm{NO}_{2}\right)$ stretching modes of the coordinated nitro ligand, respectively. ${ }^{26}$ These stretching values for bounded nitrite were close to those reported for other ruthenium complexes with similar ancillary ligands coordinated to the ruthenium center through the nitrogen atom. ${ }^{37,38}$

${ }^{1} \mathrm{H}$ NMR spectroscopy data showed 21 signals, which hydrogen integrations were consistent with the proposed formulation for compound $\mathbf{I}$.

This characterization was further achieved by single crystal X-ray diffraction studies. The crystals of X-ray quality were obtained by slow evaporation from the methanol mother liquor. The compound crystallized in the monoclinic space group $\mathrm{P}_{1} / \mathrm{c}$ (SI, Table S1). ORTEP projections are shown in Figure 1 and bond lengths and angles are given in Table S2 (SI). The structure confirms the assignment of cis geometry of the $\mathrm{NO}_{2}{ }^{-}$group in relation to 4-bzpy ligand. Additionally, this result also supported the coordination of nitro group through the nitrogen atom, as indicated by the FTIR spectrum. The dimensions of the

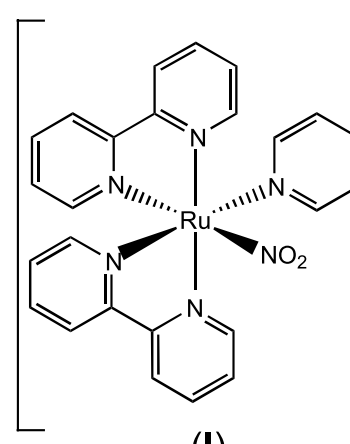

(I)

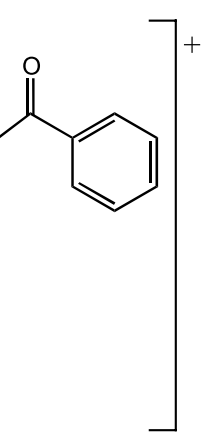

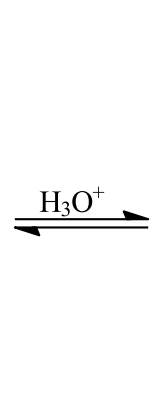

$\left(O^{2}\right)+(1)$

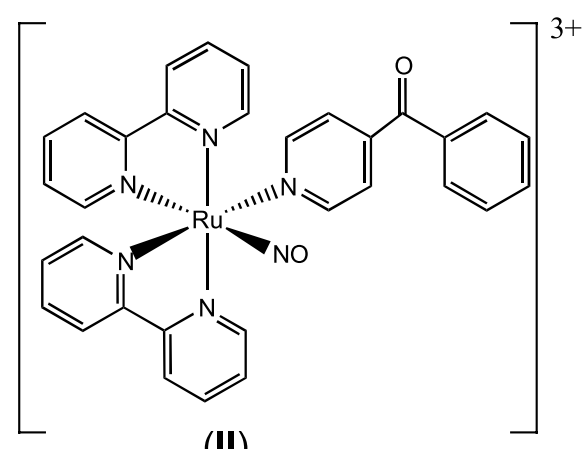

(II)

Scheme 1. Structures of the ion complexes cis-[Ru(bpy $)_{2}(4-$ bzpy $\left.)\left(\mathrm{NO}_{2}\right)\right]^{+}(\mathbf{I})$ and $c i s-\left[\mathrm{Ru}(\mathrm{bpy})_{2}(4-\mathrm{bzpy})(\mathrm{NO})\right]^{3+}$ upon acid treatment $(\mathbf{I I})$. 
nitrite ion in $\mathrm{NaNO}_{2}$ at $293 \mathrm{~K}$ were $\mathrm{N}-\mathrm{O}=1.240 \AA$ and $\mathrm{O}-\mathrm{N}-\mathrm{O}=114.9^{\circ} .{ }^{39} \mathrm{In}$ the nitro complex the $\mathrm{O}-\mathrm{N}-\mathrm{O}$ angle was $121.6^{\circ}$, within the $113-127^{\circ}$ range generally observed for $\mathrm{M}-\mathrm{NO}_{2}$ complexes and with equal $\mathrm{N}-\mathrm{O}$ bond distances $\mathrm{N}(6)-\mathrm{O}(2)=1.210(6)$ and $\mathrm{N}(6)-\mathrm{O}(1)=1.212(6) .{ }^{37,40}$ The Ru-N(6) $\left(\mathrm{NO}_{2}\right)$ interatomic distance $(2.075 \AA)$ in compound I was comparable to the values observed for other ruthenium nitro compounds, for example, 2.073(2) $\AA$ in [(p-cym) $\mathrm{Ru}($ bpy $\left.) \mathrm{NO}_{2}\right] \mathrm{PF}_{6},{ }^{37} 2.049(17) \AA$ in trans $-\left[\mathrm{Ru}\left(\mathrm{NO}_{2}\right)_{2}(\mathrm{py})_{4}\right],{ }^{41}$ and $2.072 \AA$ in $\left[\mathrm{Ru}(\text { bisox })_{2}\left(\mathrm{NO}_{2}\right)(\mathrm{NO})\right]\left(\mathrm{ClO}_{4}\right)_{2} \cdot{ }^{38}$

However, this distance is longer than the $\mathrm{Ru}-\mathrm{NO}^{+}$ bond length found in the cis-[Ru(bpy $\left.)_{2}\left(\mathrm{SO}_{3}\right)(\mathrm{NO})\right]$ $\mathrm{PF}_{6}$ compound, reflecting the greater extension of the back-bonding $\mathrm{NO}^{+} \leftarrow \mathrm{Ru}^{\mathrm{II}}$ with respect to the $\mathrm{Ru}-\mathrm{NO}_{2} \cdot{ }^{-42}$ Moreover, according to the data collected, the Ru-N(bpy) interatomic distance for the bipyridine ligands does not change significantly, varying from 2.061 (Ru-N3) to $2.091 \AA$ (Ru-N4). These results are in agreement with distances found previously for other similar complexes. ${ }^{37}$

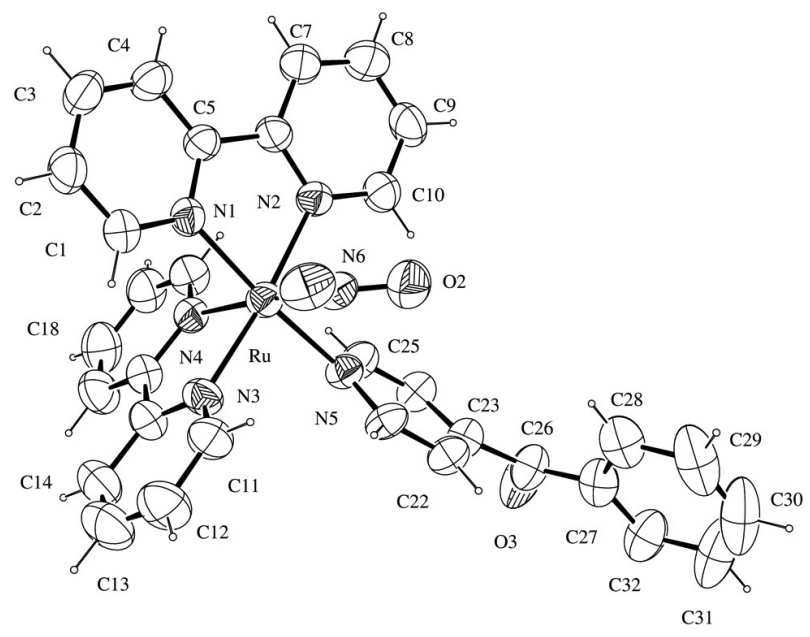

Figure 1. Ortep view of the $c i s-\left[\mathrm{Ru}(\mathrm{bpy})_{2}(4-\mathrm{bzpy})\left(\mathrm{NO}_{2}\right)\right]^{+}$, with labeling of the atoms and the $50 \%$ probability of ellipsoids.
The $c i s$-[Ru(bpy) $)_{2}$ (4-bzpy)(NO)]($\left(\mathrm{PF}_{6}\right)_{3}$, compound (II), was prepared using an acid treatment of the cis- $\left[\mathrm{Ru}(\mathrm{bpy})_{2} \text { (4-bzpy) }\left(\mathrm{NO}_{2}\right)\right]^{+}(\mathbf{I})$ aqueous solution, as shown in Scheme 1. The acid-base equilibrium for the nitrosyl-nitro interconversion of the ruthenium(II) complexes had been studied in other similar systems and has made possible to be used as a synthetic strategy. ${ }^{15}$ This equilibrium is reported as described in equation 1.

$c i s-\left[\mathrm{Ru}(\mathrm{bpy})_{2} \mathrm{~L}(\mathrm{NO})\right]^{+\mathrm{n}}+2 \mathrm{OH}^{-} \rightleftharpoons c i s-\left[\mathrm{Ru}(\mathrm{bpy})_{2} \mathrm{~L}\left(\mathrm{NO}_{2}\right)\right]^{+(\mathrm{n}-2)}+\mathrm{H}_{2} \mathrm{O}$

Thus, the synthesis of the nitrosyl complex was carried out adding a concentrated solution of trifluoroacetic acid to convert the $c i s$ - $\left[\mathrm{Ru}(\mathrm{bpy})_{2} \text { (4-bzpy) }\left(\mathrm{NO}_{2}\right)\right]^{+}$complex into cis-[Ru(bpy) $)_{2}$ (4-bzpy)(NO) $]^{3+}$. After that, the nitrosyl complex was isolated and analyzed by elemental analysis, FTIR, UV-Vis, NMR spectroscopies and electrochemical techniques.

The formation of compound (II) as the product of the acid-base equilibrium displaced in equation 1 was confirmed by analysis of the infrared spectrum (Figure S1, SI). It was noticed the disappearance of the bands at 1338 and $1303 \mathrm{~cm}^{-1}$ due to the nitro ligand, which was followed by the appearance of a new band at $1942 \mathrm{~cm}^{-1}$, typical for $\mathrm{NO}^{+}$group..$^{13,15,43}$

It is noteworthy to mention that this NO stretching frequency is higher than for cis-[Ru(bpy $\left.)_{2}\left(\mathrm{SO}_{3}\right)(\mathrm{NO})\right]$ $\left(\mathrm{PF}_{6}\right)\left(\mathrm{vNO}=1911 \mathrm{~cm}^{-1}\right),{ }^{15}$ suggesting that a relatively higher positive charge might reside on the $\mathrm{NO}^{+}$ligand. This can be due to a stronger $\pi$-acceptor character of the 4-benzoylpyridine ligand compared to sulfite. This was also observed in other similar compounds, cis- $\left[\mathrm{Ru}(\mathrm{bpy})_{2} \mathrm{~L}(\mathrm{NO})\right] \mathrm{X}_{3}$, where the $\mathrm{L}$ ligand in cis position to $\mathrm{NO}$ are also $\pi$-acceptor ligands such as imidazole (imN), isonicotinamide (isn), 4-picoline (4-pic), pyridine (py) and 4-acetylpyridine (4-acpy) (see Table 1). ${ }^{15,44}$

Table 1. Ruthenium nitrosyl complexes parameters for $c i s-\left[\mathrm{Ru}(\mathrm{bpy})_{2} \mathrm{~L}(\mathrm{NO})\right]^{3+}$

\begin{tabular}{|c|c|c|c|c|c|}
\hline $\mathrm{L}$ & $v\left(\mathrm{NO}^{+}\right) / \mathrm{cm}^{-1}$ & $\mathrm{~K}_{\mathrm{eq}}$ (equation 1) & $\mathrm{E}_{1 / 2} / \mathrm{V} v s . \mathrm{Ag} / \mathrm{AgCl}$ & $\begin{array}{c}\lambda / \mathrm{nm} \\
(\mathrm{bpy}) \pi^{*} \leftarrow \mathrm{d} \pi(\mathrm{Ru}) \mathrm{MLCT}\end{array}$ & Reference \\
\hline 4-bzpy & 1942 & $6.92 \times 10^{22}$ & 0.35 & 330 & this work \\
\hline $\mathrm{imN}$ & 1944 & $1.42 \times 10^{16}$ & 0.20 & 325 & 15 \\
\hline isn & 1948 & $1.80 \times 10^{25}$ & 0.34 & 321 & 15 \\
\hline 4-pic & 1944 & $3.80 \times 10^{20}$ & 0.31 & 332 & 44 \\
\hline py & 1947 & $1.60 \times 10^{21}$ & 0.34 & 334 & 44 \\
\hline 4-acpy & 1943 & $3.20 \times 10^{21}$ & 0.39 & 336 & 44 \\
\hline $\mathrm{SO}_{3}{ }^{2-}$ & 1911 & $1.74 \times 10^{7}$ & 0.14 & 326 & 15 \\
\hline
\end{tabular}

4-bzpy: 4-benzoylpyridine; imN = N-bounded imidazole; isn = isonicotinamide; 4-pic = 4-picoline; py = pyridine; 4-acpy = 4-acethylpyridine; $v\left(\mathrm{NO}^{+}\right)$: stretching mode for $\mathrm{NO}^{+} ; \mathrm{K}_{\text {eq }}$ : equilibrium constant based on equation $1 ; \lambda$ : maximum wavelength corresponding to the MLCT electronic transition (bpy) $\pi^{*} \leftarrow \mathrm{d} \pi(\mathrm{Ru}) ; \mathrm{E}_{1 / 2}$ : half-wave potential in volts versus $\mathrm{Ag} / \mathrm{AgCl}$ as reference electrode. 
It was observed a reversible $\mathrm{pH}$ dependence (equation 1) as revealed by the UV-Vis spectroscopic changes. These changes accompanying this acid-base reaction were collected for cis-[Ru(bpy) $)_{2}$ (4-bzpy)(NO) $]^{3+}$ (Figure 2), where it was observed a new intense band with a maximum at $417 \mathrm{~nm}$ at higher $\mathrm{pH}$. This new band can be assigned to the (bpy) $\pi^{*} \leftarrow \mathrm{d} \pi(\mathrm{Ru})$ MLCT (metal-to-ligand chargetransfer) transition of the nitro species formed due to the chemical equilibrium displayed in equation 1 . This suggestion was confirmed by the spectrum taken for the isolated nitro complex, which presented similar features. Analogous spectroscopic behavior was observed for other ruthenium nitrosyl complexes. ${ }^{15,18,43,45}$ The measured equilibrium constant $\left(\mathrm{K}_{\mathrm{eq}}\right)$ values (equation 1) for a series of similar type compounds are shown in the Table 1. Spectrophotometric titration curve for this equilibrium (equation 1) showed only one inflexion, which can be an indicative of an unique equilibrium as proposed, with $\mathrm{pH}$ of half-interconversion at 2.5 (Figure 2, inset).

The compound II was also characterized by ${ }^{1} \mathrm{H}$ NMR, COSY (correlation spectroscopy), and HMBC (heteronuclear multiple bond correlation). Figure 3 illustrates the HMBC spectrum for the compound II, where in this technique, ${ }^{1} \mathrm{H}$ nuclei are correlated to remote ${ }^{13} \mathrm{C}$ nuclei (two or three bonds away) in a $2 \mathrm{D}$ experiment, via their long-range heteronuclear $J$ couplings $\left({ }^{2} J \mathrm{CH}\right.$ and $\left.{ }^{3} J \mathrm{CH}\right) .{ }^{46}$ Only one ketone carbonyl signal $(\delta 193.3 \mathrm{ppm})$ was observed in the HMBC experiment. The cross peak

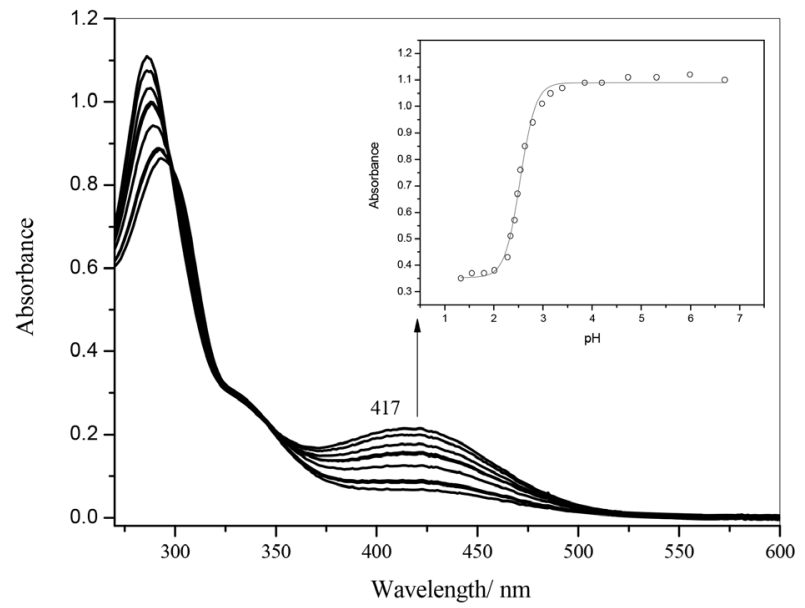

Figure 2. Spectrophotometric $\mathrm{pH}$ titration of the $c i s-\left[\mathrm{Ru}(\mathrm{bpy})_{2}(4-\mathrm{bzpy})(\mathrm{NO})\right]^{3+}$ with $\mathrm{NaOH}, \mu=0.1 \mathrm{~mol} \mathrm{~L}^{-1}, \mathrm{CH}_{3} \mathrm{COONa}$, [compound III] $=1.0 \times 10^{-4} \mathrm{~mol} \mathrm{~L}^{-1}$ (starting $\mathrm{pH}=1.3$ ). Inset: plot of the absorbance at $417 \mathrm{~nm} v s . \mathrm{pH}$.

between the ketone carbon and the peaks at $\delta 7.98$ and $7.77 \mathrm{ppm}$, observed in the HMBC experiment, led us to locate the two doublets signals of the protons corresponding to $\mathrm{H}-23 / \mathrm{H}-25$ and $\mathrm{H}-29 / \mathrm{H}-33$, respectively, as showed in the numbered structure of 4-bzpy ligand (Figure 3, inset). ${ }^{1} \mathrm{H}$ NMR spectrum showed signals of the other hydrogens present in the benzoyl ligand structure, two triplets at 7.57 and $7.72 \mathrm{ppm}$, assigned to the $\mathrm{H}-30 / \mathrm{H}-32$ and $\mathrm{H}-31$, respectively. All the signals were downfield shifted in relation to those observed for the free ligand. However, this effect is even more pronounced in the H-22/H-26

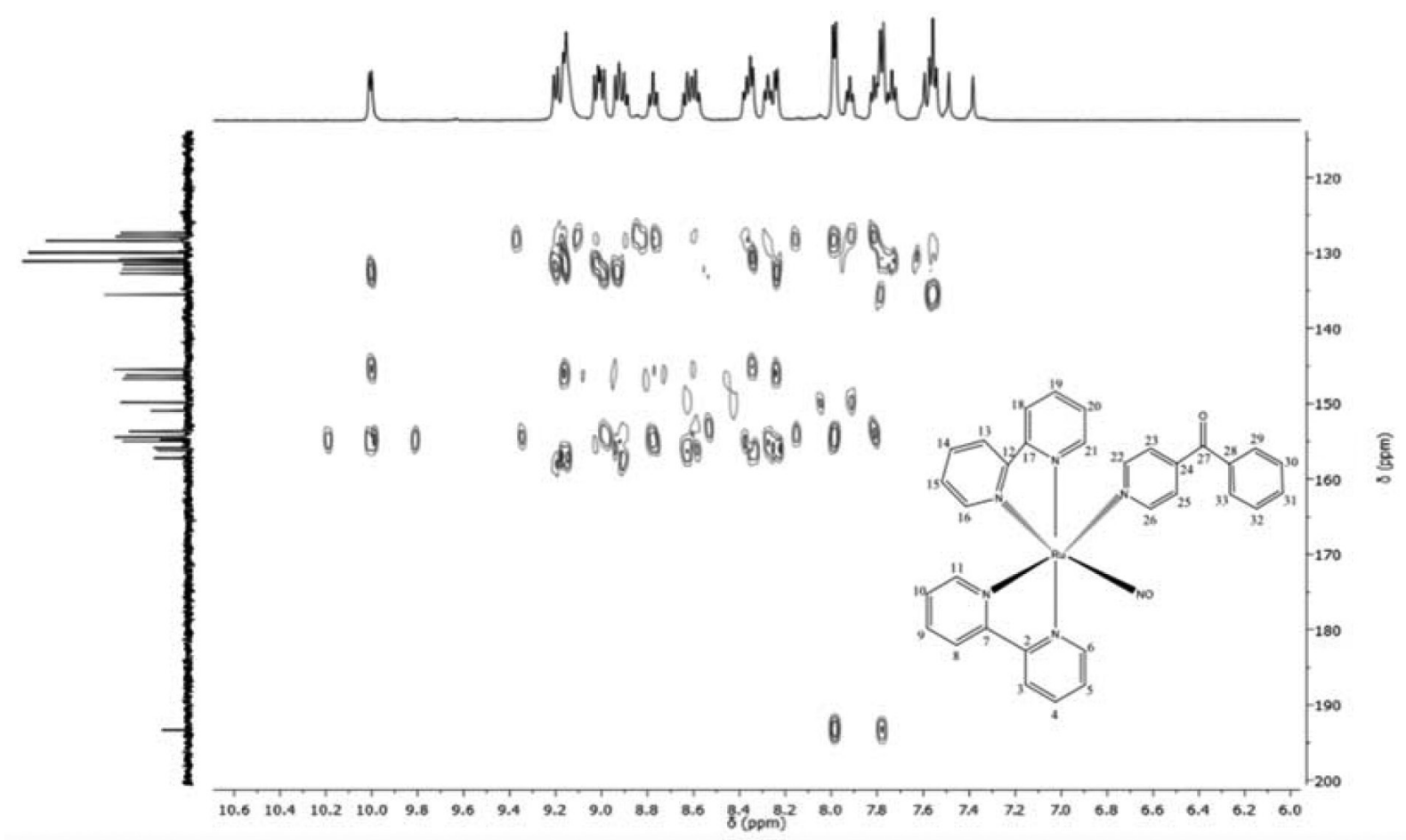

Figure 3. $\mathrm{HMBC}$ spectrum of $c i s-\left[\mathrm{Ru}(\mathrm{bpy})_{2}(4-\mathrm{bzpy})(\mathrm{NO})\right]^{3+}$ in $\mathrm{CD}_{3} \mathrm{COCD}_{3}$. Inset: numbered structure for the $c i s-\left[\mathrm{Ru}(\mathrm{bpy})_{2}(4-\text { bzpy })(\mathrm{NO})\right]^{3+}(\mathrm{compound} \mathbf{I I})$. 
( $\delta 9.15 \mathrm{ppm}$ versus $\delta 8.81 \mathrm{ppm}$ in free), due to their close proximity to the ruthenium center.

Additionally, it was observed 16 signals for the hydrogens of the two bipyridine molecules suggesting all hydrogen atoms are non diamagnetically equivalent, ${ }^{47,48}$ in agreement with the cis configuration for compound II.

The electronic spectrum of the nitrosyl complex (compound II) presented two bands at $292 \mathrm{~nm}$ $\left(\varepsilon=3.12 \times 10^{4} \mathrm{M}^{-1} \mathrm{~cm}^{-1}\right)$ and $330 \mathrm{~nm}\left(\varepsilon=8.58 \times 10^{3} \mathrm{M}^{-1} \mathrm{~cm}^{-1}\right)$. Since the complex is structurally and electronically similar to other cis- $\left[\mathrm{Ru}(\mathrm{bpy})_{2} \mathrm{~L}(\mathrm{NO})\right]^{\mathrm{nt}}$ species, where $\mathrm{L}=\mathrm{imN}$, isn, 4-pic, py, 4-acpy and $\mathrm{SO}_{3}{ }^{2--15,44}$ it is likely that their UV-Vis spectra would have some similarities. The bands observed from 321 to $336 \mathrm{~nm}$ range for the $c i s-\left[\mathrm{Ru}(\mathrm{bpy})_{2} \mathrm{~L}(\mathrm{NO})\right]^{\mathrm{n}+}$ nitrosyl complexes (Table 1) are attributed to the (bpy) $\pi^{*} \leftarrow \mathrm{d} \pi(\mathrm{Ru})$ MLCT transition. These bands are shifted to higher energy when compared to the spectra of the corresponding nitro complexes. ${ }^{15}$ This effect can be explained by the stronger $\left(\mathrm{NO}^{+}\right) \pi^{*} \leftarrow \mathrm{d} \pi(\mathrm{Ru})$ back-bonding interaction, which causes a large stabilization of the molecular orbitals that have a high contribution of the metal $\mathrm{d} \pi$ levels. The intense band observed at ca. $292 \mathrm{~nm}$ is assigned to the $\pi^{*} \leftarrow \pi$ (bpy) transition, which commonly appears in the spectra of bis(2,2-bipyridine)ruthenium(II) complexes as well. ${ }^{49}$ Unfortunately, the $\left(\mathrm{NO}^{+}\right) \pi^{*} \leftarrow \mathrm{d} \pi(\mathrm{Ru})$ transitions were not detected in the spectra, probably because of superposition with those of (bpy) $\pi^{*} \leftarrow \mathrm{d} \pi(\mathrm{Ru})$ transitions.

The electrochemical studies of the nitrosyl complex were performed using cyclic voltammetry and square wave voltammetry. The cyclic voltammogram of an aqueous solution containing the $c i s-\left[\mathrm{Ru}(\mathrm{bpy})_{2}(4-\mathrm{bzpy})(\mathrm{NO})\right]^{3+}$ complex was obtained at $\mathrm{pH}=2.0$, aiming to avoid formation of $c i s-\left[\mathrm{Ru}(\mathrm{bpy})_{2} \text { (4-bzpy) }\left(\mathrm{NO}_{2}\right)\right]^{+}$species during the potential sweep. The cyclic voltammetric waves presented a strong dependence on the initial sweep. In Figure 4 (solid line), it was shown cyclic voltammogram for a scan starting at $1.0 \mathrm{~V}$ with initial cathodic sweep, in which only one reversible electrochemical process is observed $\left(\mathrm{E}_{1 / 2}=0.35 \mathrm{~V} v \mathrm{~s} . \mathrm{Ag} / \mathrm{AgCl}\right)$ characteristic of the $\{\mathrm{RuNO}\}^{6 / 7}$ redox couple. ${ }^{15}$ On the other hand, if it started scanning at $0.0 \mathrm{~V}$ with initial anodic sweep, a second electrochemical process appeared $\left(\mathrm{E}_{1 / 2}=0.73 \mathrm{~V} v s\right.$. $\left.\mathrm{Ag} / \mathrm{AgCl}\right)$ followed by a decrease on the current wave attributed to the $\{\mathrm{RuNO}\}^{6 / 7}$ redox couple. This new process can be assigned to the $\mathrm{Ru}^{\text {IIIIII }}$ redox process of the $c i s$ - $\left[\mathrm{Ru}(\mathrm{bpy})_{2}(4-\text { bzpy })\left(\mathrm{H}_{2} \mathrm{O}\right)\right]^{2+}$ complex, which is generated by NO dissociation from compound II. Square wave voltammograms (Figure S2, SI) were also acquired for compound II aiming to reinforce this assignment. The working electrode was polarized at $0.0 \mathrm{~V}$ for different period of time before anodic sweeping started.
Interestingly, the process at $0.73 \mathrm{~V}$ was shown strongly dependent on the $\{\mathrm{RuNO}\}^{6 / 7}$ redox couple. These results suggested that there is indeed a chemical reaction promoted by reduction of the complex II $\left(\left\{\mathrm{RuNO}^{6}\right)\right.$, which then led to dissociation of $\mathrm{NO}$ and formation of aqua complex. A reasonable interpretation of the electrochemical results is proposed in equations 2-4. A similar behavior is found for other similar complexes as reported in the literature..$^{15,44}$

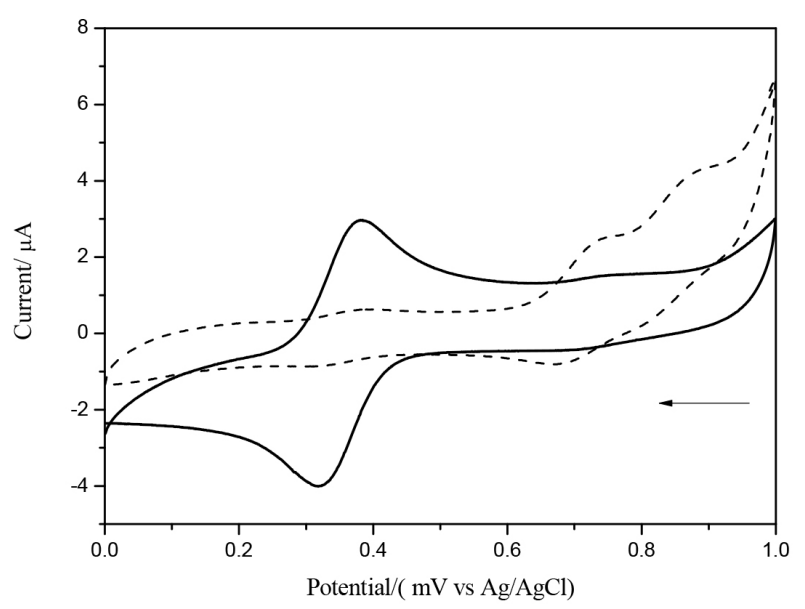

Figure 4. Cyclic voltammograms of an aqueous solution containing the cis-[Ru(bpy) $)_{2}(4-$ bzpy $\left.)(\mathrm{NO})\right]^{3+}$ complex ion, at $0.10 \mathrm{~V} \mathrm{~s}^{-1}, 0.1 \mathrm{~mol} \mathrm{~L}^{-1}$ $\mathrm{KCl}, \mathrm{pH}$ adjusted to 2.0. Solid line: starting material; dashed line: after irradiation, $\lambda_{\text {irradiation }}=453 \mathrm{~nm}$.

$$
\begin{aligned}
& c i s-\left[\mathrm{Ru}^{\mathrm{II}}(\mathrm{bpy})_{2} \mathrm{~L}\left(\mathrm{NO}^{+}\right)\right]^{3+}+\mathrm{e}^{-} \stackrel{0.35 \mathrm{~V}}{\rightleftharpoons} c i s-\left[\mathrm{Ru}^{\mathrm{II}}(\mathrm{bpy})_{2} \mathrm{LNO}^{0}\right]^{2+}
\end{aligned}
$$

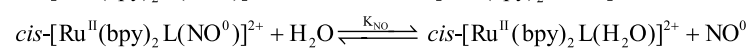

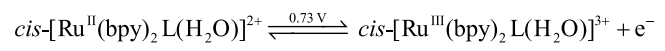

The $\mathrm{E}_{1 / 2}$ for the $\{\mathrm{RuNO}\}^{6 / 7}$ process in the cis-[Ru(bpy $)_{2}(4$-bzpy)(NO) $]\left(\mathrm{PF}_{6}\right)_{3}$ complex was similar to the other compounds as displayed in Table 1 along with other data, $v\left(\mathrm{NO}^{+}\right)$and equilibrium constants $\left(\mathrm{K}_{\mathrm{eq}}\right.$, equation 1) for correlation purposes. Based on the data in Table 1, there was a reasonable correlation between the nitrosyl-nitro equilibrium $\mathrm{K}_{\mathrm{eq}}, v\left(\mathrm{NO}^{+}\right)$, and $\mathrm{E}_{1 / 2}$. Compounds that exhibited major $\mathrm{NO}^{+}$character, indicated by a higher $v\left(\mathrm{NO}^{+}\right)$, had also shown larger $\mathrm{K}_{\mathrm{eq}}$ values in the whole series. In fact, the greater the electron deficiency on the $\mathrm{NO}^{+}$moiety, resulting from the $\pi$-acid character of the $\left[\mathrm{Ru}(\mathrm{bpy})_{2} \mathrm{~L}\right]^{2+}$ group, the larger is going to be the driving force for the reaction of the coordinated $\mathrm{NO}^{+}$with $\mathrm{OH}^{-}$, which is due to the increase in the electrophilicity of this moiety (equation 1). The $\mathrm{E}_{1 / 2}$ values were also in agreement with the $v\left(\mathrm{NO}^{+}\right)$and $\mathrm{K}_{\mathrm{eq}}$ data (equation 1), and reflected well the influence of electronic effects on the reactivity of the nitrosyl metal complexes. In addition, a good correlation between $\mathrm{E}_{1 / 2}\{\mathrm{RuNO}\}^{6 / 7}$ and $v\left(\mathrm{NO}^{+}\right)$is observed for the series of nitrosyl complexes. The lower redox potential of the $\{\mathrm{RuNO}\}^{6 / 7}$ redox couple has been associated also 
to lower $\mathrm{v}\left(\mathrm{NO}^{+}\right)$, which is in agreement with the decrease in the electronic density of the $\mathrm{NO}^{+}$group caused by the higher $\pi$ acceptor character of the L ligand.

\section{Photochemical studies}

The compound II showed high stability in solution and solid state, if protected against light. However, it can release NO upon light irradiation when dissolved in aqueous medium, according to equation 5. Also, after irradiation in the solid state, the compound was able to release NO.

$$
\begin{gathered}
c i s-\left[\mathrm{Ru}^{\mathrm{II}}(\mathrm{bpy})_{2}(4-\text { bzpy }) \mathrm{NO}^{+}\right]^{3+} \stackrel{\text { hv }}{\longrightarrow}\left\{c i s-\left[\mathrm{Ru}^{\mathrm{III}}(\text { bpy })_{2}(4-\text { bzpy })\left(\mathrm{NO}^{\circ}\right)\right]^{3+}\right\}^{*}+\mathrm{H}_{2} \mathrm{O}+\mathrm{e}^{-} \\
\downarrow \\
\text { cis }\left[\mathrm{Ru}(\text { bpy })_{2}(4-\text { bzpy })\left(\mathrm{H}_{2} \mathrm{O}\right)\right]^{2+}+\mathrm{NO}^{0}
\end{gathered}
$$

In a preliminary investigation, it was observed that light irradiation at 365, 453 and $505 \mathrm{~nm}$ induced photochemical reactivity. These experiments were carried out in aqueous medium, $\mathrm{pH}=2.0$. Despite the lower quantum yield using longer wavelength light, it was still possible to cause NO photorelease, which was an important result in face of the potential use in phototherapy. The final product of photolysis was identified by comparing the UV-Vis spectrum, electrochemical, NMR and infrared data with those of authentic samples of previously characterized cis-[Ru(bpy $)_{2}(4-$ bzpy $\left.)\left(\mathrm{H}_{2} \mathrm{O}\right)\right]^{2+}$ complex ion. All these results supported the photochemical product as described in equation 5. This light-driven reaction creates an excited state species, usually due to an MLCT transition band involving mainly ruthenium-based HOMO orbital $(\mathrm{d} \pi)$ to
NO-based LUMO orbital $\left(\pi^{*}\right)$. This process would lead to a transient charge separation species, $\mathrm{Ru}^{\mathrm{III}}-\mathrm{NO}^{0}$ (equation 5), as proposed by Franco and co-workers. ${ }^{50}$ This singlet state would undergo an interconversion and intersystem crossing pathway to a lower energy triplet excited states, which would promote solvation and NO release as described elsewhere. ${ }^{50,51}$

Rose and Mascharak ${ }^{52}$ had proposed that the photochemical behavior of the $\{\mathrm{RuNO}\}^{6}$ regarding to the NO release could work by two types of mechanisms: the first one produces $\mathrm{NO}$ and [ $\mathrm{Ru}^{\mathrm{III}}$-solvent], while the second generates $\mathrm{NO}$ and $\left[\mathrm{Ru}^{\mathrm{II}}\right.$-solvent] as final products. The first type of mechanism is noticed for the Ru-nitrosyl complexes having ammine, carboxamide, thiolate, heme and phenolate as auxiliary ligands, whereas the second type contained polypyridines and Schiff base as auxiliary ligands. In the mechanism of the second type, despite it is not very clear how, the formation of $\mathrm{Ru}^{\mathrm{II}}$ species seems to proceed from a reduction of the transient $\mathrm{Ru}^{\mathrm{III}}$ species mediated by light. ${ }^{52,53}$ In our case, the irradiations conducted at 365,453 and $505 \mathrm{~nm}$ showed profile compatible to $\mathrm{Ru}^{\mathrm{II}}-\mathrm{H}_{2} \mathrm{O}$ species as supported by UV-Vis, ${ }^{1} \mathrm{H}$ NMR and electrochemical techniques in accordance with the photochemical reaction proposed (equation 5).

A comparison of the ${ }^{1} \mathrm{H}$ NMR spectra acquired before and after irradiation at $453 \mathrm{~nm}$ (Figures 5A and $5 \mathrm{C}$, respectively) showed that cis-[Ru(bpy) ${ }_{2}$ (4-bzpy) $\mathrm{NO}^{3+}$ was converted into the final product within $1 \mathrm{~h}$. Interestingly, ${ }^{1} \mathrm{H}$ NMR spectra of the photo reaction product (Figure 5C) and the product of the reaction between cis-[Ru(bpy) $)_{2}$ (4-bzpy)NO $]^{3+}$ and $\mathrm{NaN}_{3}$ (in solution

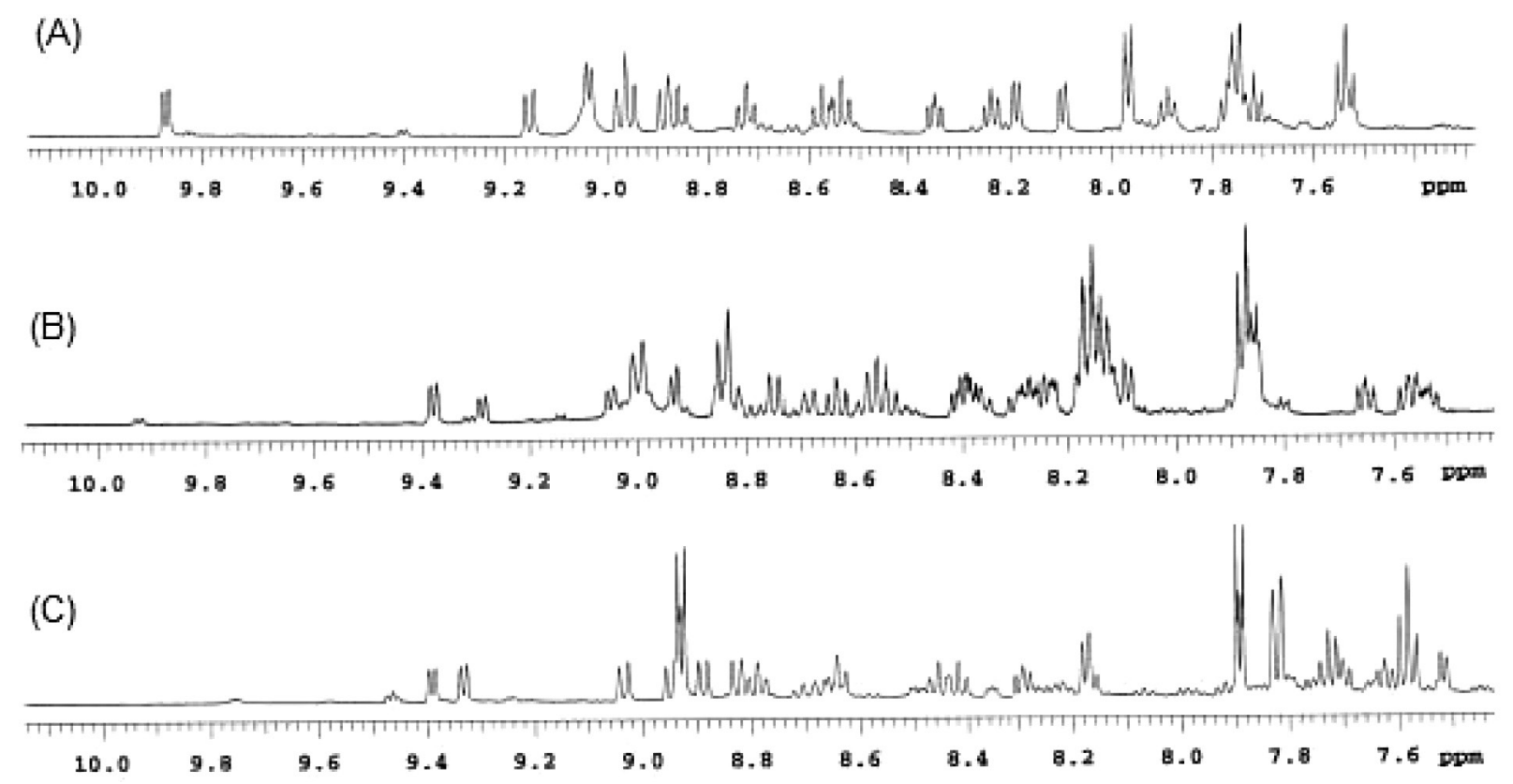

Figure 5. ${ }^{1} \mathrm{H}$ NMR spectrum of $c i s-\left[\mathrm{Ru}(\text { bpy })_{2}(4-\text { bzpy)NO }]^{3+}\right.$ complex in $\mathrm{CD}_{3} \mathrm{COCD}_{3} / \mathrm{D}_{2} \mathrm{O}$ (10:90). (A) Complex kept in the dark; (B) complex after reaction with a stoichiometric amount of $\mathrm{N}_{3}^{-} ;(\mathrm{C})$ complex after $1 \mathrm{~h}$ of blue light irradiation $\left(\lambda_{\text {irradiation }}=453 \mathrm{~nm}\right)$. 
$10 \%$ acetone, $90 \% \mathrm{H}_{2} \mathrm{O}$ ) (Figure 5B) had reasonable similarities. The azide reaction with nitrosonium species is well described in the literature and used in reaction with metallonitrosyl complex to remove bound $\mathrm{NO}^{+}$yielding the solvent-bound complex. ${ }^{54,55}$

This photochemical reaction was also monitored by cyclic voltammetry (Figure 4, dashed line), where the release of NO as a photoproduct was confirmed by the increase of the current intensity at $0.85 \mathrm{~V}$ versus $\mathrm{Ag} / \mathrm{AgCl}$ assigned to free NO oxidation. ${ }^{14}$ Moreover, a well-defined reversible redox process appeared with $\mathrm{E}_{1 / 2}$ at $0.73 \mathrm{~V}$. This latter process was assigned to the $\mathrm{Ru}^{\text {IIIIII }}$ redox process for cis-[Ru(bpy $)_{2}(4$-bzpy $\left.)\left(\mathrm{H}_{2} \mathrm{O}\right)\right]^{2+}$, which should be generated as a result of dissociation of $\mathrm{NO}$ from the original compound. This was further supported by changes in the electronic spectra (Figure 6), where it was noticed an increase of the MLCT band $\left(\pi^{*}(\mathrm{bpy}) \leftarrow \mathrm{d} \pi(\mathrm{Ru})\right)$ at $450 \mathrm{~nm}$, which is typical of the $c i s$ - $\left[\mathrm{Ru}(\mathrm{bpy})_{2}(4 \text {-bzpy })\left(\mathrm{H}_{2} \mathrm{O}\right)\right]^{2+}$ species generated after the release of NO (Figure S3, SI).

In addition, photochemical reaction in the solid state was also investigated using infrared spectroscopy (Figure S4, SI). It was observed a continuous decrease of the peak at $1942 \mathrm{~cm}^{-1}$, assigned to the $v \mathrm{NO}^{+}$, upon light irradiation $\left(\lambda_{\text {irradiation }}=365,453\right.$ and $\left.505 \mathrm{~nm}\right)$. These data are consistent with the release of NO due to the photolysis.

Quantitative studies were conducted to measure quantum yield $(\varphi)$ for the photoreaction depicted in equation 5 . The quantum yields were $0.20 \pm 0.05,0.010 \pm 0.004$ and $0.0072 \pm 0.002$, for light irradiation at 365,453 and $505 \mathrm{~nm}$, respectively (Figures S5-S7, SI). These values were obtained based on changes in the absorption spectrum of the aqueous solution of $c i s-\left[\mathrm{Ru}(\mathrm{bpy})_{2}(4-\mathrm{bzpy})(\mathrm{NO})\right]^{3+}$ upon light irradiation as described in Experimental section and seems to reflect differences in the absorptivity of the compound.

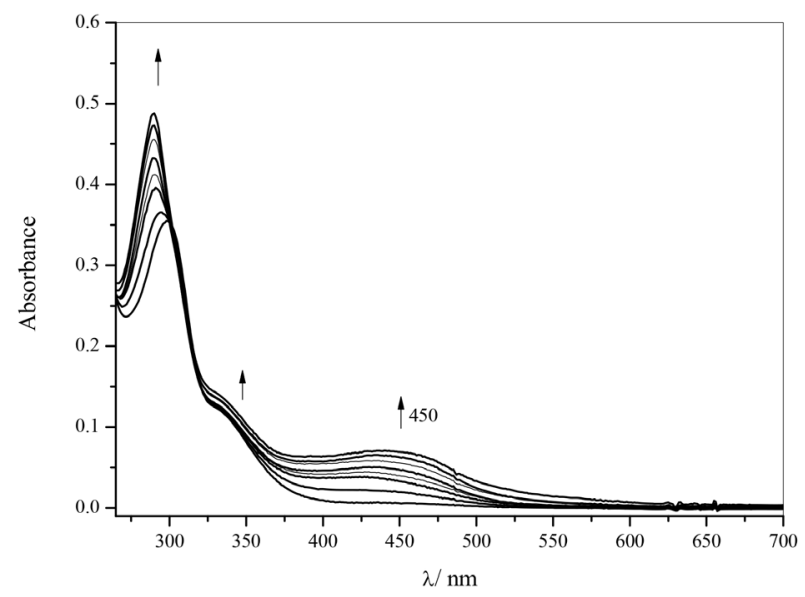

Figure 6. Spectral changes of the absorption spectrum accompanying photolysis of $c i s-\left[\mathrm{Ru}(\mathrm{bpy})_{2}(4-\mathrm{bzpy})(\mathrm{NO})\right]^{3+}$ in aqueous solution, $\mathrm{pH}=2.0$, $\lambda_{\text {irradiation }}=505 \mathrm{~nm}$.
Remarkably, compound II showed a significant release of NO upon light irradiation using a blue-green LED with $\lambda_{\max }$ at $505 \mathrm{~nm}$ (Figure 6 and Figure S4, SI). So far, there are only a few examples of nitrosyl complexes that deliver NO upon irradiation with such lower energy light. ${ }^{53,56}$ Therefore, the $c i s-\left[\mathrm{Ru}(\mathrm{bpy})_{2}(4-\mathrm{bzpy}) \mathrm{NO}\right]^{3+}$ may be considered a promising releasing agent model of NO to be used in phototherapy.

Considering the potential role of $\mathrm{NO}$ as a bactericide and in cancer therapy, many efforts have been directed to the development of metal nitrosyl complexes able to release NO in a controlled way, such as using light, more particularly close to $600-1100 \mathrm{~nm}$. This spectroscopic range falls within the phototherapeutic window, where light has the greatest penetrating capacity in the skin, and could hence be useful as a non-invasive clinical therapy. ${ }^{57,58}$ Even though this range is routinely investigated in the search for photoactivatable metal complexes and appropriate light sources are available, there is also interest in using other wavelengths in the treatment of superficial tumors and development of appropriate light source. For example, blue light is already being successfully employed in therapy. ${ }^{59,60} \mathrm{So}$, cis-[Ru(bpy $)_{2}$ (4-bzpy)NO $]^{3+}$ compound has an important feature supporting its potential application in phototherapy.

Taking into account that metal-based drug should be stable in physiological $\mathrm{pH}$, we also investigated if the nitro complex (compound I) could function as a source of NO upon irradiation. The experiments were carried out at $\mathrm{pH} 7.4$, where the nitro species is observed in greater quantity in comparison to nitrosyl. The spectral changes upon photolysis of aqueous complex I with a blue LED (Figure S8, SI) showed a decrease in the MLCT absorption at $417 \mathrm{~nm}$ and the appearance of the new band at $\lambda_{\max }$ at $450 \mathrm{~nm}$, indicating the formation of aqua species. Silva and co-workers ${ }^{53}$ observed a similar behavior for a series of complexes of the type $c i s$ - $\left[\mathrm{Ru}(\mathrm{bpy})_{2}(\mathrm{~L})\left(\mathrm{NO}_{2}\right)\right]^{+}$(where $\mathrm{L}=$ pyridine, 4-picoline or pyrazine). These researchers suggested even a bound nitrite undergoes photochemical disproportionation to produce NO in aqueous solution. This process has also been investigated and supported by other investigators. ${ }^{61,62}$

The reaction of $c i s-\left[\mathrm{Ru}(\mathrm{bpy})_{2}(4-\mathrm{bzpy})(\mathrm{NO})\right]^{3+}$ with cysteine

During the last years, some labs have investigated the reaction of thiol-containing biomolecules with nitrosyl metallocompounds. This has been motivated by their relative large concentrations in biological medium, whose reaction with metallonitrosyl could eventually define the actual biological fate of these compounds in vivo. 


$$
\begin{aligned}
{\left[(\mathrm{X})_{5} \mathrm{RuNO}^{\mathrm{n}} \underset{-\mathrm{RS}^{-}}{\stackrel{\mathrm{RS}^{-}}{\rightleftharpoons}}\left[(\mathrm{X})_{5} \mathrm{RuN}(\mathrm{O}) \mathrm{SR}\right]^{\mathrm{n}-1} \underset{\mathrm{RS}^{-}}{\stackrel{\mathrm{RS}^{-}}{\rightleftharpoons}}\left[(\mathrm{X})_{5} \mathrm{RuN}(\mathrm{O})(\mathrm{SR})_{2}\right]^{\mathrm{n}-2}\right.} \\
\downarrow \\
\\
\\
\quad\left[(\mathrm{X})_{5} \mathrm{Ru}\left(\mathrm{H}_{2} \mathrm{O}\right)\right]^{\mathrm{n}-1}+\frac{1}{2} \mathrm{~N}_{2} \mathrm{O}+\mathrm{RSSR}
\end{aligned}
$$

Scheme 2. Proposed mechanism for the reaction of $\left[\mathrm{Ru}(\mathrm{bpy})_{2} \mathrm{~L}(\mathrm{NO})\right]^{\mathrm{n}+}$ with thiols.

Roncaroli and Olabe ${ }^{63}$ and Silva et al.${ }^{64}$ studied this reaction with several nitrosyl complex type $\left[\mathrm{Ru}(\mathrm{bpy})_{2} \mathrm{~L}(\mathrm{NO})\right]^{\mathrm{n}+}$ and trans- $\left[\mathrm{Ru}\left(\mathrm{NH}_{3}\right)_{4} \mathrm{~L}(\mathrm{NO})\right]^{3+}$ and reported that it occurred by the general following mechanism (Scheme 2):

Interestingly, the reaction of $\left[\mathrm{Ru}(\mathrm{bpy})_{2} \mathrm{~L}(\mathrm{NO})\right]^{\mathrm{n}+}$ ( $\mathrm{L}=$ sulfite, imidazole) with cysteine and glutathione showed qualitative evidences for the production of $\mathrm{NO} \cdot{ }^{15}$ More recently, the reaction of the trans- $\left[\mathrm{Ru}\left(\mathrm{NH}_{3}\right)_{4} \mathrm{P}(\mathrm{OEt})_{3} \mathrm{NO}\right]$ $\left(\mathrm{PF}_{6}\right)_{3}$ with cysteine was investigated and showed the generation of both HNO and NO. ${ }^{65}$

Here, we have investigated the reaction of cis-[Ru(bpy $\left.)_{2}(4-\mathrm{bzpy})(\mathrm{NO})\right]^{3+}$ with cysteine using stoppedflow technique. The experiments were carried out at $\mathrm{pH} 2.2$ and $37^{\circ} \mathrm{C}$, in a pseudo-first order condition, where at least a 10-fold excess of cysteine was employed.

The reaction of cysteine with compound II exhibited a fast spectroscopic changes (Figure 7) lasting around 10 seconds. However, the first spectrum, recorded at the very beginning of this mixture, showed already a band with maximum at ca. $450 \mathrm{~nm}$, assigned to the first intermediate, likely the $\left\{\mathrm{L}_{5} \mathrm{RuN}(\mathrm{O}) \mathrm{SR}\right\}$ adducts also reported in other similar systems. Unfortunately, it was not possible to monitor the formation of this first intermediate, even by stoppedflow technique. This was indeed consistent with an expected very fast kinetic constant for this first step, considering a redox process for $\mathrm{Ru}^{\mathrm{II}}-\mathrm{NO}^{+}$at $0.35 \mathrm{~V} v s$. $\mathrm{Ag} / \mathrm{AgCl}$, as reported elsewhere. ${ }^{63}$ For longer acquisition times, at the expense of this band, a new absorption band was observed at ca. $372 \mathrm{~nm}$ likely due to the electronic transitions of the second intermediate, $\left\{\mathrm{L}_{5} \mathrm{RuN}(\mathrm{O}) \mathrm{SR}(\mathrm{SR})\right\}$.

The third and final step of the reaction is the conversion of the second intermediate into the final product, which was characterized as the aqua species, $c i s$ - $\left[\mathrm{Ru}(\mathrm{bpy})_{2}\right.$ (4-bzpy) $\left.\left(\mathrm{H}_{2} \mathrm{O}\right)\right]^{2+}$ (Figure 7). The assignment of the final product as the aqua complex was based on the electrochemical and UV-Vis measurements, which were consistent with previously published data for other $\left[\mathrm{Ru}(b p y) \mathrm{L}\left(\mathrm{H}_{2} \mathrm{O}\right)\right]^{\mathrm{n}+}$ type complexes. ${ }^{66}$ It was clearly observed a decrease in the absorbance of the band at ca. $372 \mathrm{~nm}$, referring to the second intermediate, followed by an increase of a band at ca. $450 \mathrm{~nm}$. The isosbestic point observed at $407 \mathrm{~nm}$ indicated a single step reaction. The same behavior is observed for similar systems, with $\mathrm{L}=\mathrm{SO}_{3}{ }^{2-}$ and $\mathrm{ImN}^{64}$ and for $\left[\mathrm{Fe}(\mathrm{CN})_{5} \mathrm{NO}\right]^{2-}$. 33,67 The observed kinetic constants were measured for the formation of the second
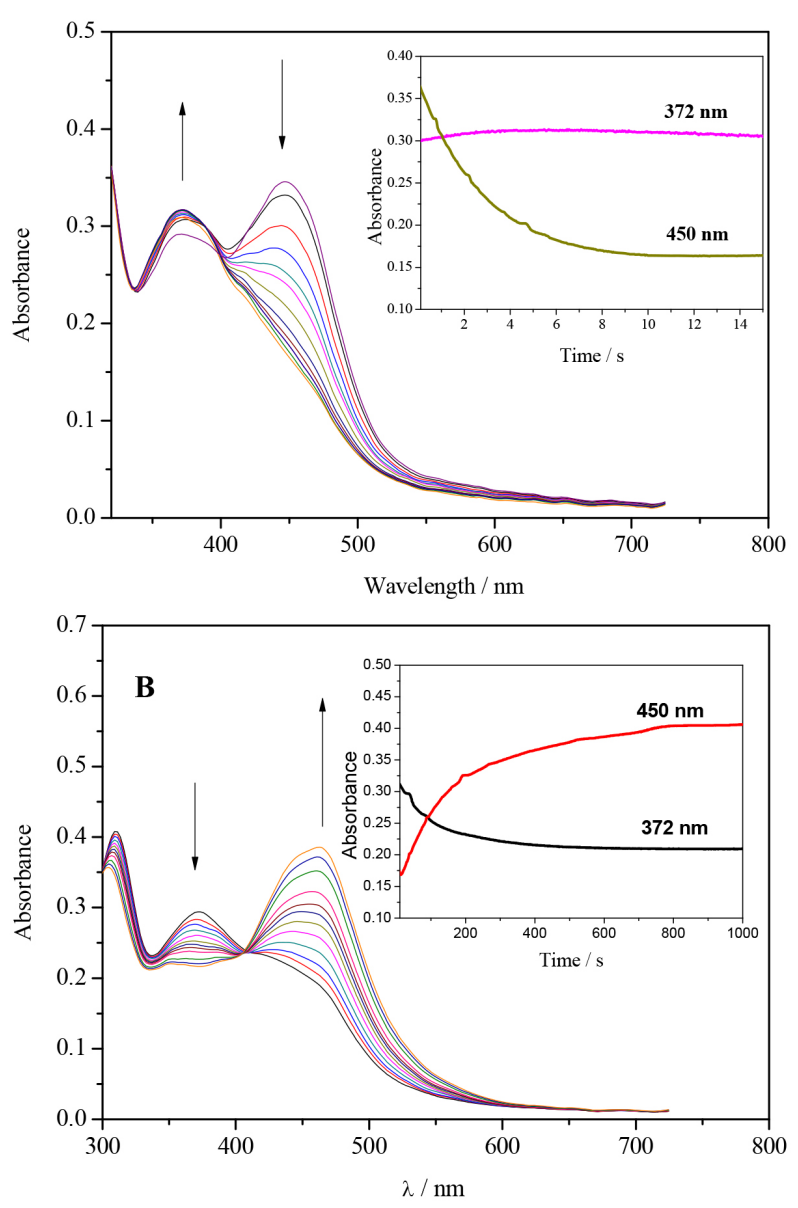

Figure 7. Spectra changes for the reaction of $c i s-\left[\mathrm{Ru}(\mathrm{bpy})_{2}(4-\mathrm{bzpy}) \mathrm{NO}\right]^{3+}$ $\left([\right.$ compound $\left.\mathbf{I I}]=8.5 \times 10^{-4} \mathrm{~mol} \mathrm{~L}^{-1}\right)$ with cysteine ([cysteine] $\left.=8.5 \times 10^{-3} \mathrm{~mol} \mathrm{~L}^{-1}\right), \mathrm{pH}=2.2,\left(\mu=0.1 \mathrm{~mol} \mathrm{~L}^{-1}\right)$ in citrate/ phosphate buffer, at $37{ }^{\circ} \mathrm{C}$, monitored by stopped-flow technique. (A) Monitoring of the reaction during the first 12 seconds; (B) monitoring of the reaction during 1100 seconds. Insets show the kinetic traces at different wavelengths.

intermediate and the final product with $\mathrm{k}_{2(\mathrm{obs})}=0.0437 \mathrm{~s}^{-1}$ and $\mathrm{k}_{3(\mathrm{obs})}=0.00402 \mathrm{~s}^{-1}$, respectively. Attempts to further characterize the first and second intermediates are ongoing.

Aiming to validate the release of NO during the reaction with cysteine, we employed a commercial NO sensor and an electrode modified method. This latter was reported by our group, ${ }^{31}$ and it is based on the modification of a gold electrode with trans-[Fe(cyclam) $\left.(\mathrm{NCS})_{2}\right]^{+}$complex ion. The electrochemical current for NO oxidation on this modified electrode was significantly enhanced in comparison to bare Au electrode, along with a great linear correlation for analytical measurements, enabling its use 
for NO detection. Qualitative measurements of NO release during the reaction with cysteine were observed using a NO sensor measurements. Additionally, the modified electrode technique showed NO signal only upon addition of cysteine to a solution containing the $c i s$ - $\left[\mathrm{Ru}(\mathrm{bpy})_{2}(4-\mathrm{bzpy}) \mathrm{NO}\right]^{3+}$ complex (Figure S9, SI).

Attempts to verify if this reaction also produce HNO, as observed by Pereira et al. ${ }^{68}$ and Sousa et al. ${ }^{69}$ are being conducted in our laboratory and will be further published.

Vasodilation assay

NO is a powerful vasorelaxant agent, and the measurement of such effect is an important bioassay to check both the potency and efficacy of a new NO donor candidate. The dose-response curve for compound II was performed in order to obtain the concentration that causes maximum vasorelaxation, presumably via an intracellular reduction mechanism. In these experiments aorta rings were pre-contracted with $0.1 \mu \mathrm{mol} \mathrm{L}{ }^{-1}$ phenylephrine, and when the contraction had reached the plateau, compound II was cumulatively added from $1 \mathrm{pmol} \mathrm{L}^{-1}$ to $100 \mu \mathrm{mol} \mathrm{L}^{-1}$ (Figure 8). Additionally, at the end of this experiment, the tissue was recontracted to guarantee tissue integrity and rule out any damage promoted by the complex. The maximal relaxant response to compound II was $207 \pm 10 \%$, while the maximal relaxation induced by SNP was $149.9 \pm 8.2 \%$. Therefore, compound II had a greater efficacy as a vessel relaxant that does SNP $(\mathrm{p}=0.002)$. Nevertheless, the $\mathrm{EC}_{50}$ for SNP $\left(13.3 \mathrm{nmol} \mathrm{L}^{-1}\right)$ was 52-fold smaller than the $\mathrm{EC}_{50}$ for $c i s-\left[\mathrm{Ru}(\mathrm{bpy})_{2}(4-\mathrm{bzpy}) \mathrm{NO}\right]^{3+}\left(690 \mathrm{nmol} \mathrm{L}^{-1}\right)$. Based on these results, cis-[Ru(bpy $)_{2}(4-$ bzpy $\left.) \mathrm{NO}\right]^{3+}$ has a very good efficiency as a vasodilator with a potency that is 52 -fold lower than SNP. Considering that SNP has

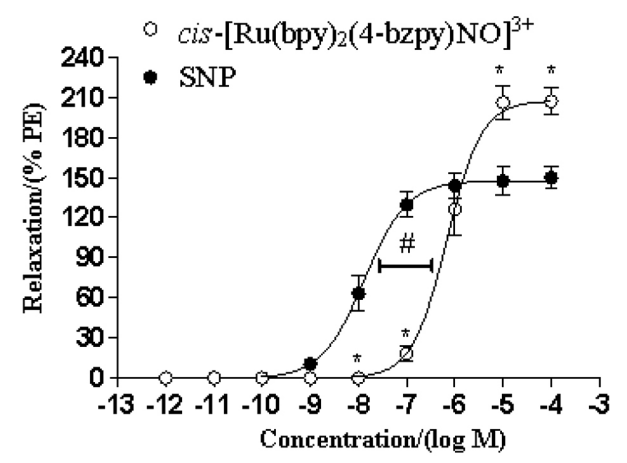

Figure 8. Effect of $c i s-\left[\mathrm{Ru}(\mathrm{bpy})_{2}(4-\mathrm{bzpy}) \mathrm{NO}\right]^{3+}$ and sodium nitroprusside (SNP) on aortic vascular endothelium rings. The rings were precontracted with $0.1 \mu \mathrm{M}$ phenylephrine and relaxation concentration/response curves (concentration graded from $1 \mathrm{pmol} \mathrm{L}^{-1}$ to $100 \mu \mathrm{mol} \mathrm{L}^{-1}$ ) were plotted for cis-[Ru(bpy) $\left.{ }_{2}(4-b z p y) N O\right]^{3+}$ and compared with SNP curves. Findings are expressed as mean \pm standard error, based on five independent experiments. ${ }^{*} \mathrm{p}<0.01 \mathrm{vs}$. SNP; \#: $\mathrm{EC}_{50}$ for $\mathrm{SNP} v s . \mathrm{EC}_{50}$ for $c i s-\left[\mathrm{Ru}(\mathrm{bpy})_{2}(4-\mathrm{bzpy}) \mathrm{NO}\right]^{3+}$. the disadvantage of cyanide generation, which does not occur with compound II, this might be a lead compound in the search of new nitrovasodilators to treat angina and hypertensive crisis. Nevertheless, we should remark that there is no cytotoxic data supporting compound II is indeed less toxic than SNP. In fact, the lack of cyanide in its structure cannot guarantee it is non-toxic, which will be further investigated.

\section{Conclusion}

A new nitrosyl complex was prepared where a blue-green light irradiation showed the release of NO species, a feature that makes this compound of particular interest for future application in phototherapy. Another interesting feature of this compound is the ability to react with cysteine, an abundant thiol compound found in physiological medium, leading to the release of nitric oxide. Unfortunately, this complex had still a low $\mathrm{pH}$ for nitro-nitrosyl equilibrium conversion, which might limit its full application (e.g. stomach). However, our results of vasodilation assay suggest that $c i s$ - $\left[\mathrm{Ru}(\mathrm{bpy})_{2}\right.$ (4-bzpy) $\mathrm{NO}]^{3+}$ is indeed a promising NO donor agent promoting a concentration-dependent relaxation in rat aortic rings, even at physiological condition. Despite the lack of toxicity studies, these results are quite encouraging and might eventually lead this compound to become a relevant pharmacological agent.

\section{Supplementary Information}

Supplementary information is available free of charge at http://jbcs.sbq.org.br.

\section{Acknowledgments}

The authors are thankful to Brazilian agencies CAPES, CNPq (L. G. F. Lopes 303732/2014-8; E. H. S. Sousa 312030/2015-0), FUNCAP (PPSUS 12535691-9, PRONEX PR2 0101-00030.01.00/15), CAPES (23038.008968/2012-87) for financial support.

\section{References}

1. Murad, F.; Angew. Chem., Int. Ed. 1999, 38, 1857.

2. Furchgott, R. F.; Angew. Chem., Int. Ed. 1999, 38, 1870.

3. Ignarro, L. J.; Ballot, B.; Wood, K. S.; J. Biol. Chem. 1984, 259 , 6201.

4. Ignarro, L. J.; Buga, G. M.; Wood, K. S.; Byrns, R. E.; Chaudhuri, G.; Proc. Natl. Acad. Sci. U. S. A. 1987, 84, 9265.

5. Ignarro, L. J.; Pharm. Res. 1989, 6, 651. 
6. Moncada, S.; Palmer, R. M. J.; Gryglewski, R. J.; Proc. Natl. Acad. Sci. U. S. A. 1986, 83, 9164.

7. Bonaventura, D.; de Lima, R. G.; Vercesi, J. A.; da Silva, R. S.; Bendhack, L. M.; Vasc. Pharmacol. 2007, 46, 215.

8. Pavanelli, W. R.; da Silva, J. J.; Panis, C.; Cunha, T. M.; Costa, I. C.; de Menezes, M. C. N. D.; Oliveira, F. J. A.; Lopes, L. G. F.; Cecchini, R.; Cunha, F. Q.; Watanabe, M. A. E.; Itano, E. N.; Mycopathologia 2011, 172, 95.

9. Campelo, M. W. S.; Oria, R. B.; Lopes, L. G. D.; Brito, G. A. D.; dos Santos, A. A.; de Vasconcelos, R. C.; da Silva, F. O. N.; Nobrega, B. N.; Bento-Silva, M. T.; de Vasconcelos, P. R. L.; Neurochem. Res. 2012, 37, 749.

10. Santana, A. P. M.; Tavares, B. M.; Lucetti, L. T.; Gouveia, F. S.; Ribeiro, R. A.; Soares, P. M. G.; Sousa, E. H. S.; Lopes, L. G. F.; Medeiros, J. V. R.; Souza, M. H. L. P.; Nitric Oxide 2015, 45,35 .

11. Staurengo-Ferrari, L.; Mizokami, S. S.; Silva, J. J.; da Silva, F. O. N.; Sousa, E. H. S.; da Franca, L. G.; Matuoka, M. L.; Georgetti, S. R.; Baracat, M. M.; Casagrande, R.; Pavanelli, W. R.; Verri, W. A.; Pharmacol., Biochem. Behav. 2013, 105, 157.

12. Leitao Junior, A. S.; Campos, R. M.; Cerqueira, J. B.; Fonteles, M. C.; Santos, C. F.; de Nucci, G.; Sousa, E. H.; Lopes, L. G.; Gonzaga-Silva, L. F.; Nascimento, N. R.; Int. J. Impotence Res. 2016, 28, 20.

13. Holanda, A. K. M.; da Silva, F. O. N.; Carvalho, I. M. M.; Batista, A. A.; Ellena, J.; Castellano, E. E.; Moreira, I. S.; Lopes, L. G. F.; Polyhedron 2007, 26, 4653.

14. Holanda, A. K. M.; da Silva, F. O. N.; Sousa, J. R.; Diogenes, I. C. N.; Carvalho, I. M. M.; Moreira, I. S.; Clarke, M. J.; Lopes, L. G. F.; Inorg. Chim. Acta 2008, 361, 2929.

15. Silva, F. O. N.; Araujo, S. X. B.; Holanda, A. K. M.; Meyer, E.; Sales, F. A. M.; Diogenes, H. C. N.; Carvalho, I. M. M.; Moreira, I. S.; Lopes, L. G. F.; Eur. J. Inorg. Chem. 2006, 2020.

16. Nakamura, G.; Kondo, M.; Crisalli, M.; Lee, S. K.; Shibata, A.; Ford, P. C.; Masaoka, S.; Dalton Trans. 2015, 44, 17189.

17. Franco, L. P.; Cicillini, S. A.; Biazzotto, J. C.; Schiavon, M. A.; Mikhailovsky, A.; Burks, P. T.; Garcia, J. V.; Ford, P. C.; Silva, R. S.; J. Phys. Chem. A 2014, 118, 12184.

18. Candido, M. C. L.; Oliveira, A. M.; Silva, F. O. N.; Holanda, A. K. M.; Pereira, W. G.; Sousa, E. H. S.; Carneiro, Z. A.; Silva, R. S.; Lopes, L. G. F.; J. Braz. Chem. Soc. 2015, 26, 1824.

19. Fogler, E.; Efremenko, I.; Gargir, M.; Leitus, G.; Diskin-Posner, Y.; Ben-David, Y.; Martin, J. M. L.; Milstein, D.; Inorg. Chem. 2015, 54, 2253.

20. Becker, T.; Kupfer, S.; Wolfram, M.; Görls, H.; Schubert, U. S.; Anslyn, E. V.; Dietzek, B.; Gräfe, S.; Schille, A.; Chem. - Eur. J. 2015, 21, 15554.

21. Doro, F. G.; Pepe, I. M.; Galembeck, S. E.; Carlos, R. M.; da Rocha, Z. N.; Bertotti, M.; Tfouni, E.; Dalton Trans. 2011, 40, 6420 .
22. Oliveira, F. D.; Ferreira, K. Q.; Bonaventura, D.; Bendhack, L. M.; Tedesco, A. C.; Machado, S. D.; Tfouni, E.; da Silva, R. S.; J. Inorg. Biochem. 2007, 101, 313.

23. Sauaia, M. G.; Oliveira, F. D.; Tedesco, A. C.; da Silva, R. S.; Inorg. Chim. Acta 2003, 355, 191.

24. Sullivan, B. P.; Salmon, D. J.; Meyer, T. J.; Inorg. Chem. 1978, 17, 3334 .

25. Enraf-Nonius; COLLECT, Nonius BV: Delft, The Netherlands, 1997-2000.

26. Godwin, J. B.; Meyer, T. J.; Inorg. Chem. 1971, 10, 2150.

27. Sheldrick, G. M.; Acta Crystallogr., Sect. A 2008, 64, 112.

28. Calvert, J. G.; Pitts Jr., J. N.; Photochemistry; John Wiley \& Sons, Inc.: New York, 1966.

29. Sheldrick, G. M.; SHELXL-97, Program for Crystal Structures Analysis, University of Göttingen: Göttingen, Germany, 1997.

30. Demas, J. N.; Crosby, G. A.; J. Phys. Chem. 1971, 75, 991.

31. Santos, V. N.; Mendonca, G. L. F.; Freire, V. N.; Holanda, A. K. M.; Sousa, J. R.; Lopes, L. G. F.; Ellena, J.; Correia, A. N.; de Lima-Neto, P.; Electrochim. Acta 2013, 91, 1.

32. Otwinowski, Z.; Minor, W.; Methods Enzymol. 1997, $276,307$.

33. Blessing, R. H.; Acta Crystallogr., Sect. A 1995, 51, 33.

34. Hintze, R. E.; Ford, P. C.; Inorg. Chem. 1975, 14, 1211.

35. Yumata, N. C.; Habarurema, G.; Mukiza, J.; Gerber, T. I. A.; Hosten, E.; Taherkhani, F.; Nahali, M.; Polyhedron 2013, 62, 89.

36. Cotton, F. A.; Wilkinson, G.; Advanced Inorganic Chemistry; Wiley \& Sons: New York, 1988.

37. Freedman, D. A.; Kruger, S.; Roosa, C.; Wymer, C.; Inorg. Chem. 2006, 45, 9558.

38. Drew, M. G. B.; Nag, S.; Datta, D.; Dalton Trans. 2008, 2298.

39. Kay, M. I.; Frazer, B. C.; Acta Crystallogr. 1961, 14, 56.

40. Bessel, C. A.; See, R. F.; Jameson, D. L.; Churchill, M. R.; Takeuchi, K. J.; J. Chem. Soc., Dalton Trans. 1993, 1563.

41. Buron-Le Cointe, M.; Cormary, B.; Toupet, L.; Malfant, I.; Acta Crystallogr. Sect. C: Struct. Chem. 2011, C67, m375.

42. Silva, J. J. N.; Guedes, P. M. M.; Zottis, A.; Balliano, T. L.; Silva, F. O. N.; Lopes, L. G. F.; Ellena, J.; Oliva, G.; Andricopulo, A. D.; Franco, D. W.; Silva, J. S.; Br. J. Pharmacol. 2010, 160, 260.

43. Holanda, A. K. M.; Pontes, D. L.; Diogenes, I. C. N.; Moreira, I. S.; Lopes, L. G. F.; Transition Met. Chem. 2004, 29, 430.

44. Sauaia, M. G.; da Silva, R. S.; Transition Met. Chem. 2003, 28 , 254.

45. Andriani, K. F.; Caramori, G. F.; Doro, F. G.; Parreira, R. L. T.; Dalton Trans. 2014, 43, 8792.

46. Paiva, D. L.; Lampman, G. M.; Kriz, G. S.; Vyvyan, J. R.; Introduction to Spectroscopy, $4^{\text {th }}$ ed.; Cengage Learning: Belmont, 2009.

47. Llanguri, R.; Morris, J. J.; Stanley, W. C.; Bell-Loncella, E. T.; Turner, M.; Boyko, W. J.; Bessel, C. A.; Inorg. Chim. Acta 2001, 315, 53. 
48. Brissard, M.; Convert, O.; Gruselle, M.; Guyard-Duhayon, C.; Thouvenot, R.; Inorg. Chem. 2003, 42, 1378.

49. Callahan, R. W.; Meyer, T. J.; Inorg. Chem. 1977, 16, 574.

50. Tfouni, E.; Krieger, M.; McGarvey, B. R.; Franco, D. W.; Coord. Chem. Rev. 2003, 236, 57.

51. Greene, S. N.; Richards, N. G. J.; Inorg. Chem. 2004, 43, 7030.

52. Rose, M. J.; Mascharak, P. K.; Coord. Chem. Rev. 2008, 252, 2093.

53. Lima, G. R.; Sauaia, M. G.; Bonaventura, D.; Tedesco, A. C.; Loppez, R. F. V.; Bendhack, L. M.; Silva, R. S.; Inorg. Chim. Acta 2005, 358, 2643.

54. Raichart, D. W.; Taube, H.; Inorg. Chem. 1972, 11, 999.

55. Meyer, T. J.; Miller, F. J.; J. Am. Chem. Soc. 1971, 93, 1294.

56. da Rocha, Z. N.; de Lima, R. G.; Doro, F. G.; Tfouni, E.; da Silva, R. S.; Inorg. Chem. Commun. 2008, 11, 737.

57. Masters, B. R.; So, P. T. C.; Gratton, E.; Biophys. J. 1997, 72, 2405.

58. Diwu, Z. J.; Lown, J. W.; Pharmacol. Ther. 1994, 63, 1.

59. Radu, A.; Conde, R.; Fontolliet, C.; Wagnieres, G.; Van den Bergh, H.; Monnier, P.; Gastrointest. Endosc. 2003, 57, 897.

60. Brancaleon, L.; Moseley, H.; Lasers Med. Sci. 2002, 17, 173.

61. da Rocha, Z. N.; Marchesi, M. S. P.; Molin, J. C.; Lunardi, C. N.; Miranda, K. M.; Bendhack, L. M.; Ford, P. C.; da Silva, R. S.; Dalton Trans. 2008, 4282.
62. Carlos, R. M.; Cardoso, D. R.; Castellano, E. E.; Osti, R. Z.; Camargo, A. J.; Macedo, L. G.; Franco, D. W.; J. Am. Chem. Soc. 2004, 126, 2546.

63. Roncaroli, F.; Olabe, J. A.; Inorg. Chem. 2005, 44, 4719.

64. Silva, F. O. N.; Candido, M. C. L.; Holanda, A. K. M.; Diogenes, I. C. N.; Sousa, E. H. S.; Lopes, L. G. F.; J. Inorg. Biochem. 2011, 105, 624.

65. Pereira, J. C. M.; Sousa, M. L.; Franco, D. W.; Eur. J. Inorg. Chem. 2015, 1005.

66. Durham, B.; Wilson, S. R.; Hodgson, D. J.; Meyer, T. J.; J. Am. Chem. Soc. 1980, 102, 600.

67. Butler, A. R.; Megson, I. L.; Chem. Rev. 2002, 102, 1155.

68. Pereira, J. C. M.; Souza, M. L.; Franco, D. W.; Eur. J. Inorg. Chem. 2015, 1005.

69. Sousa, E. H. S.; Ridnour, L. A.; Gouveia, F. S.; da Silva, C. D. S.; Wink, D. A.; Lopes, L. G. D.; Sadler, P. J.; ACS Chem. Biol. 2016, 11, 2057.

Submitted: November 14, 2016

Published online: March 27, 2017 